\title{
Changes in metabolic profiling of sugarcane leaves induced by endophytic diazotrophic bacteria and humic acids
}

\author{
Natalia O Aguiar ${ }^{1}{ }^{\text {, Fabio L Olivares }}{ }^{1}$, Etelvino H Novotny ${ }^{2}$, Luciano P Canellas ${ }^{\text {Corresp. } 1}$ \\ ${ }^{1}$ Núcleo de Desenvolvimento de Insumos Biológicos para a Agricultura (NUDIBA), Universidade Estadual do Norte Fluminense, Campos dos Goytacaes, \\ Rio de Janeiro, Brazil \\ 2 Embrapa Solos, Rio de Janeiro, Rio de Janeiro, Brazil \\ Corresponding Author: Luciano P Canellas \\ Email address: canellas@uenf.br
}

Plant growth promoting bacteria (PGPB) and humic acids (HA) have been used as biostimulants in field conditions. The complete genomic and proteomic transcription of Herbaspirillum seropedicae and Gluconacetobacter diazotrophicus is available but interpreting and utilizing this information in the field to increase crop performance is challenging. The identification and characterization of metabolites that are induced by genomic changes may be used to improve plant responses to inoculation. The objective of this study was to describe changes in sugarcane metabolic profile that occur when HA and PGPB are used as biostimulants. Inoculum was applied to soil containing 45-day old sugarcane stalks. One week after inoculation, the methanolic extracts from leaves were obtained and analyzed by gas chromatography coupled to time-of-flight mass spectrometry; a total of 1,880 compounds were observed and 280 were identified in all samples. The application of HA significantly decreased the concentration of 15 metabolites, which generally included amino acids. HA increased the levels of 40 compounds, and these included metabolites linked to the stress response (shikimic, caffeic, hydroxycinnamic acids, putrescine, behenic acid, quinoline xylulose, galactose, lactose proline, oxyproline and valeric acid) and cellular growth (adenine and adenosine derivatives, ribose, ribonic acid and citric acid). Similarly, PGPB enhanced the level of metabolites identified in HA-treated soils; e.g. 48 metabolites were elevated and included amino acids, nucleic acids, organic acids, and lipids. Co-inoculation (HA+PGPB) boosted the level of 110 metabolites with respect to non-inoculated controls; these included amino acids, lipids and nitrogenous compounds. Changes in the metabolic profile induced by HA+PGPB influenced both glucose and pentose pathways and resulted in the accumulation of heptuloses and riboses, which are substrates in the nucleoside biosynthesis and shikimic acid pathways. The mevalonate pathway was also activated, thus increasing phytosterol synthesis. The improvement in cellular metabolism observed with PGPB+HA was compatible with high levels of vitamins. Glucuronate and amino sugars were 
stimulated in addition to the products and intermediary compounds of tricarboxylic acid metabolism. Lipids and amino acids were the main compounds induced by co-inoculation in addition to antioxidants, stress-related metabolites, and compounds involved in cellular redox. The primary compounds observed in each treatment were identified, and the effect of co-inoculation (HA+PGPB) on metabolite levels was discussed. 
7 1Núcleo de Desenvolvimento de Insumos Biológicos para a Agricultura (NUDIBA),

8 Universidade Estadual do Norte Fluminense Darcy Ribeiro (UENF), Av. Alberto Lamego, 2000,

9 Campos dos Goytacazes 28013-602 Rio de Janeiro, Brazil

10 2Embrapa Solos - Rua Jardim Botânico, 1024, Rio de Janeiro 22460-000, Rio de Janeiro, Brazil

11 Author for correspondence: Luciano P Canellas

12 E-mail: canellas@uenf.br

13 Running head: Foliar metabolic changes induced by inoculation

14 Highlights

15 - Metabolic profile of sugarcane leaves was changed by inoculation

16 - Tricarboxylic acid, shikimic acid and mevalonate pathways were induced

17 - Compounds related to the plant stress response were detected

18 - Humic acids amplified the metabolic response induced by diazotrophic bacteria 
19 Abstract

Plant growth promoting bacteria (PGPB) and humic acids (HA) have been used as 21 biostimulants in field conditions. The complete genomic and proteomic transcription of 22 Herbaspirillum seropedicae and Gluconacetobacter diazotrophicus is available but interpreting 23 and utilizing this information in the field to increase crop performance is challenging. The 24 identification and characterization of metabolites that are induced by genomic changes may be used to improve plant responses to inoculation. The objective of this study was to describe changes in sugarcane metabolic profile that occur when HA and PGPB are used as biostimulants. Inoculum was applied to soil containing 45-day old sugarcane stalks. One week after inoculation, the methanolic extracts from leaves were obtained and analyzed by gas chromatography coupled to time-of-flight mass spectrometry; a total of 1,880 compounds were observed and 280 were identified in all samples. The application of HA significantly decreased the concentration of 15 metabolites, which generally included amino acids. HA increased the levels of 40 compounds, and these included metabolites linked to the stress response (shikimic, caffeic, hydroxycinnamic acids, putrescine, behenic acid, quinoline xylulose, galactose, lactose proline, oxyproline and valeric acid) and cellular growth (adenine and adenosine derivatives, ribose, ribonic acid and citric acid). Similarly, PGPB enhanced the level of metabolites identified in HA-treated soils; e.g. 48 metabolites were elevated and included amino acids, nucleic acids, organic acids, and lipids. Co-inoculation (HA+PGPB) boosted the level of 110 metabolites with respect to noninoculated controls; these included amino acids, lipids and nitrogenous compounds. Changes in the metabolic profile induced by HA+PGPB influenced both glucose and pentose pathways and resulted in the accumulation of heptuloses and riboses, which are substrates in the nucleoside biosynthesis and shikimic acid pathways. The mevalonate pathway was also activated, thus increasing phytosterol synthesis. The improvement in cellular metabolism observed with PGPB $+\mathrm{HA}$ was compatible with high levels of vitamins. Glucuronate and amino sugars were stimulated in addition to the products and intermediary compounds of tricarboxylic acid metabolism. Lipids and amino acids were the main compounds induced by co-inoculation in addition to antioxidants, stress-related metabolites, and compounds involved in cellular redox. The primary compounds observed in each treatment were identified, and the effect of coinoculation (HA+PGPB) on metabolite levels was discussed. 


\section{Introduction}

50

Plant inoculation technology is a secure and environmentally-friendly technology that saves approximately 3 billion dollars per year in Brazil by decreasing the application of nitrogen fertilizers in soybean and others leguminous plants (Alves et al., 2003). This technology has considerable potential for non-leguminous plants (Reis et al., 2008). Current scientific efforts are focused on the isolation and selection of plant-beneficial microorganisms and their application in soil-plant systems in controlled conditions (Vassilev et al. 2015).

Despite the genomic sequencing efforts of Herbaspirillum seropedicae and Gluconacetobacter diazotrophicus (Bertalan et al., 2009; Pedrosa et al., 2011), the field responses of sugarcane inoculation with plant growth promoting bacteria (PGPB) are far from those results obtained in experimental conditions (Oliveira et al., 2009; Carvalho et al., 2014; Schultz et al., 2014). Da Silva et al. (2017) applied a suspension containing humic acids (HA) and PGPB on sugarcane foliage and verified a 37\% increase in productivity (26 tons ha ${ }^{-1}$ ) during the first year as compared to the control. The positive growth promotion in sugarcane coinoculated with $\mathrm{HA}$ and $H$. seropedicae persisted for three years (sugarcane plant and two ratoons). Furthermore, an experiment utilizing large pots containing inoculated sugarcane (emulating commercial plantations) showed larger yields than non-inoculated plants for three consecutive years, further proving the benefits of co-inoculating with HA and PGPB.

Field efficiency is a key aspect for bioinoculant acceptance and wider agricultural use (Bhattacharyya and Jha, 2012; Owen et al., 2015). Olivares et al. (2017) reviewed the use of HA and PGPB on non-leguminous plants and showed different morphological adaptations and physiological changes induced by co-inoculation. The study of plant metabolite levels has contributed significantly to our understanding of plant physiology, particularly from the viewpoint of small chemical molecules that reflect the end point of biological pathways (Hong et al., 2016). Changes in the metabolic profile of plants treated with inoculants may further decrease the gap between field and laboratory results. Furthermore, the recognition of cell metabolites altered by inoculation is fundamental for the identification of specific molecular targets. Therefore, the aim of this work was to characterize the changes in the metabolic profile of sugarcane co-inoculated with HA and H. seropedicae and G. diazotrophicus.

\section{Materials and methods}


Humic acids (HA) and plant growth promoting bacteria (PGPB)

0

Humic substances were extracted and purified as reported elsewhere (Aguiar et al., 2013). Briefly, 10 volumes of $0.5 \mathrm{~mol} \mathrm{~L}^{-1} \mathrm{NaOH}$ were mixed with one volume of earthworm compost, under a $\mathrm{N}_{2}$ atmosphere and shaken overnight. After $12 \mathrm{~h}$, the suspension was centrifuged at $5,000 \mathrm{~g}$ and acidified to a $\mathrm{pH}$ of $1.5 \mathrm{using} 6 \mathrm{~mol} \mathrm{~L}-1 \mathrm{HCl}$. The HAs were solubilized in $0.5 \mathrm{~mol} \mathrm{~L}^{-1} \mathrm{NaOH}$ and precipitated three times. The sample was repeatedly washed with water until a negative test against $\mathrm{AgNO}_{3}$. The $\mathrm{HAs}$ were titrated to a $\mathrm{pH}$ of 7.0 with 0.1 mol L-1 $\mathrm{KOH}$ then dialyzed against deionized water using a $1 \mathrm{kD}$ cutoff membrane (Thomas Scientific, Swedesboro, NJ) before they were lyophilized.

Mixed inoculum containing Gluconacetobacter diazotrophicus strain PAL5 and Herbaspirillum seropedicae strain HRC54 was used in this experiment, both originally isolated from sugarcane in Brazil and characterized as endophytic diazotrophs (Cavalcante and Dobereiner, 1988; Olivares et al., 1996), and being part of the five-species inoculant recommended for sugarcane in Brazil (Schultz et al., 2016). For pre-inoculum preparation, both bacteria species were grown in $5 \mathrm{~mL}$ liquid DIGYS medium at $30{ }^{\circ} \mathrm{C}$ for 36 hours at $140 \mathrm{rpm}$ in rotatory shaker (Baldani et al., 2014). Later, $50 \mu \mathrm{L}$ of each bacterial species was inoculated in separated in $500 \mathrm{~mL}$ erlenmeyer containing freshly liquid DIGYS at the same growing condition for 48 hours. Bacteria biomass produced was centrifuged at $5.000 \mathrm{~g}$ for 10 minutes and resuspended in sterilized water, being adjusted for a cell density of $10^{8}$ cells. $\mathrm{mL}^{-1}$ that correspond to O.D. of 1.0 at $440 \mathrm{~nm}$. The inoculant was prepared by diluting $100 \mathrm{~mL}$ of each bacterial suspension in $800 \mathrm{~mL}$ of distilled water (bacteria treatment) or in $800 \mathrm{~mL}$ humic acid solution at pH 6.5 (bacteria + humic acid treatment), as well $200 \mathrm{~mL}$ of distilled water plus 800 $\mathrm{mL}$ of humic acid solution (humic acid treatment) and $1000 \mathrm{ml}$ of distilled water (control treatment).

Plant assay

Before the planting, we perform the heat treatment and cane stalks were immersed water $\left(50^{\circ} \mathrm{C}\right)$ by $2 \mathrm{~h}$. The sugarcane cultivar RB 967515 was used for pot experiments. We use the superficial layer $(0-20 \mathrm{~cm})$ of a typical soil used to sugarcane plantation in Rio de Janeiro state and classified as Inceptisol. The soil chemical properties were analyzed according to Embrapa methods described in Claessen et al., (1997): $\mathrm{pH}\left(\mathrm{H}_{2} \mathrm{O}\right)=5.5 ; \mathrm{Al}=3 \mathrm{mmol}_{\mathrm{c}} \mathrm{dm}^{-3}$ (titration 
109 against $\mathrm{NaOH}$ ); $\mathrm{Ca}=7 \mathrm{mmol}_{\mathrm{c}} \mathrm{dm}^{-3}$ and $\mathrm{Mg}=4 \mathrm{mmol}_{\mathrm{c}} \mathrm{dm}^{-3}$ (titration against EDTA); $\mathrm{P}=4.0 \mathrm{mg}$

$110 \mathrm{dm}^{-3}$ (Mehlich 1 extraction and colorimetric determination); $\mathrm{K}=33 \mathrm{mg} \mathrm{dm}{ }^{-3}$ (Mehlich 1

111 extraction and flame photometric determination). The randomized complete block design

112 (RCBD) was used as experimental design with four treatments and three replicates. The

113 treatments consisted of a final bacteria suspension at $4 \times 10^{8}$ cell $\mathrm{mL}^{-1}$, humic substances at 50

$114 \mathrm{mg} \mathrm{C} \mathrm{L}{ }^{-1}$ or its combination which were applied at the same time directly in the soil at 45 days

115 after germination leaf bud at rate of $400 \mathrm{~mL}$ per pot. Control treatment was performed applying

116 water at the same volume. The plants were irrigated to keep soil moisture at field capacity. The

117 leaves were collected after 7 days of treatments application to metabolomic profile analyze.

118 Sugarcane sample processing and metabolite extraction

119 Sugarcane leaves were collected under controlled conditions, ground in the $\mathrm{N}_{2}$ 120 homogenizer and stored at $-80^{\circ} \mathrm{C}$. Metabolites were extracted using $20 \mathrm{mg}$ of fresh weight 121 sample adding $1 \mathrm{~mL}$ of pre-chilled extraction solution (80:20 v/v solvent mixture of 122 methanol/water). The samples were vortex for $10 \mathrm{~s}$ and shake for 6 minutes followed 123 by centrifugation for $10 \mathrm{~min}$ at $10,000 \mathrm{~g}$. We remove the whole supernatant in two $500 \mu \mathrm{L}$ 124 portions, saving one as a backup. One portion was dried and submitted to derivatization.

125 GC-TOF mass spectrometry

126 Derivatization was performed as described previously (Fiehn et al., 2008). In summary, $1272 \mu \mathrm{L}$ of a C8-C30 FAME mixture was used to convert retention times to retention index (RI). 128 Carbonyl groups were protected by $10 \mu \mathrm{L}$ of a solution of $20 \mathrm{mg} \mathrm{mL}^{-1}$ methoxyamine in pyridine 129 at $30^{\circ} \mathrm{C}$ for $90 \mathrm{~min}$. Ninety microliters of MSTFA and 1\% TMCS was added for 130 trimethylsilylation of acidic protons at $37^{\circ} \mathrm{C}$ for $30 \mathrm{~min}$. After derivatization $0.5 \mu \mathrm{L}$ samples 131 were injected in randomized sequence into a Gerstel cold injection system (Gerstel, Muehlheim, 132 Germany) and Agilent 7890A gas chromatograph (Santa Clara, CA) in split less mode. The 133 system was controlled by the Leco ChromaTOF software versus 2.32 (St. Joseph, MI). A 30 m

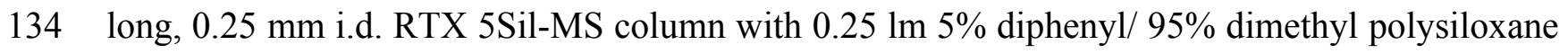
135 film and additional $10 \mathrm{~m}$ integrated guard column was used (Restek, Bellefonte, PA). Injection 136 temperature was $230^{\circ} \mathrm{C}$, the interface was set to $280^{\circ} \mathrm{C}$. Helium flow was $1 \mathrm{~mL} \mathrm{~min}{ }^{-1}$. After a 5 137 min solvent delay time at $50^{\circ} \mathrm{C}$, oven temperature was increased at $20^{\circ} \mathrm{C} \mathrm{min}{ }^{-1}$ to $330^{\circ} \mathrm{C}, 5 \mathrm{~min}$ 
138 isocratic, cool down to $50^{\circ} \mathrm{C}$ and additional 5 min delay, afterwards. Liners were exchanged 139 automatically every 10 samples. A Leco Pegasus IV time-of-flight mass spectrometer was 140 operated at a transfer line temperature of $280^{\circ} \mathrm{C}$, ion source was adjusted at $250^{\circ} \mathrm{C}$ and $-70 \mathrm{~V}$ 141 electron impact ionization. Mass spectra were acquired at mass resolving power $\mathrm{R}=600$ from $142 \mathrm{~m} / \mathrm{z} 85$ to 500 at 17 spectra $\mathrm{s}^{-1}$. The results files were exported to a data server with absolute 143 spectra intensities and further processed by a filtering algorithm implemented in the 144 metabolomics Bin-Base database (Fiehn et al., 2005).

145 Quantification was reported as peak height using the unique ion as default, unless a 146 different quantification ion was manually set in the BinBase administration software 147 Bellerophon. Metabolites were unambiguously assigned by the Bin-Base identifier numbers, 148 using retention index and mass spectrum as the two most important identification criteria. All 149 database entries in BinBase were matched against the Fiehn mass spectral library of 1,200 150 authentic metabolite spectra and the NIST05 commercial library (Kind et al., 2009). A 151 quantification report table was produced for all database entries that were positively detected in 152 more than $50 \%$ of the samples of a study design class as defined in the SetupX database (Scholz 153 and Fiehn, 2007).

Multivariate analysis

The metabolite data were then normalized based on the cell dry weight in each sample.

157 The resulting data sets, which comprised 12 samples and 285 variables, were imported into The 158 Unscramble software (version 10.1, Camo Co., Norway) for multivariate statistical and analysis 159 (Fiehn et al., 2008; Lee and Fiehn, 2008) and univariate analysis (Anova and Dunnet mean test 160 against the control).

\section{Results}

162

We found 1,885 different compounds in sugarcane leaves extracts and 280 were found in 163 all samples and with accurate identification according similarity to chemical standard of Fiehn 164 library used in this work (Lee and Fiehn, 2008). The identified compounds were mainly of 165 carbohydrates (30\%), organic acids (16\%), lipids (17\%), amino acids (9\%), aromatics $(11 \%)$, 166 others nitrogenous compounds besides amino acids (12\%) and other compounds (2\%). Identified 
167 compounds were sorted according its chemical classification. The values represent percentage 168 difference of the concentration in relation to the control according to the significance analysis of 169 the variance (Table 1-6). In general, humic acid (HA treatment) induced decreased amount of

170 larger number of compounds in respect to control, except for aromatics compounds. For bacteria 171 inoculation (PGPB treatment), remarkable increase of amino acids metabolism and nitrogenous 172 biosynthesis related to control plants were observed. Combined application (HA + PGPB 173 treatment) displayed the highest number of compounds related to the control (Figure 1). 174 Hereafter, we expose the main results according the biochemical category of leaves metabolites.

\section{Carbohydrates (Table 1)}

All treatments induce the concentration of these sugars: glucose, glucose-1-P, galactose,

177 levanbiose, lactobionic acid, mannose, hexopyranose, deoxyerythriol and sialicin (amino sugar).

178 In the HA treatments we found nine carbohydrates that have its concentration reduced in respect 179 to control. With the inoculation this number was reduced to six and PGPB+HA to zero. The 180 main compounds decreased by HA were: 1,5 anhydrous gluciol (-80\%), leucrose (-66\%), two 181 generic disaccharides described by numbers 200391 and 553367 in the Fiehn library (-36 and $18252 \%$, respectively), melibiose (-61\%) and fucose (-60\%). sucrose-6-phosphate (-42\%). The sugar 183 decreased by inoculation were 2-ketogulonic acid, the carbohydrate 208845 and the raffinose ($18450 \%$ ). The carbohydrates founded in larger concentration with HA treatment were raffinose and 185 ribose $(548 \%)$, lactose $(+510 \%)$, xylulose $(+458 \%)$, salicin $(+211 \%)$, among others with less 186 increase. The sugars enhanced by bacteria inoculation were erythrol lactone, gluco heptulose, 187 melibiose, 1-deoxy pentiol and two disaccharides (267647 and 285065). The PGPB+HA enhance 188 the concentration of ribito $(+825 \%)$, isomaltose $(+586 \%)$, melezitose $(+533 \%)$, glucose-6189 phosphate $(+413 \%)$, sophorose $(+297 \%)$, glycerol-gluco heptose $(+258 \%)$, enolpyruvate $190(+246 \%)$, tagalose $(+220 \%)$, hexose amino-2-deoxy $(192 \%)$, erythrol $(+169 \%)$, trehalose $191(+133 \%)$, galactose-6-P (+107\%) and fucose (+44\%). It was notable the increase of melibiose 192 with inoculation enhancing from $943 \%$ to $4143 \%$ when the inoculation was done in the presence 193 of HA.

194 Amino acids (Table 2) 

including asparagine (-85\%) and glutamine (-72\%) and enhance significantly lysine (+306\%), 5aminovaleric acid $(+211 \%)$, isoleucine $(+45 \%)$, proline $(+278 \%)$ and oxoproline $(+26 \%)$. The PGPB and PGPB+HA enhanced the amino acid metabolism increasing mostly including aspartic acid (from 122 to $629 \%$ ), asparagine (177 to 937\%), glutamic acid (254\%), glutamine (1038\% to $595 \%$ ), homoserine (216 to $640 \%$ ), isoleucine (88 to $135 \%$ ), $\mathrm{N}$-methyl alanine (100\%), ornithine ( $247 \%$ to $425 \%$ ), hydroxyproline (94 to $369 \%$ ), proline (1031 to $1155 \%$ ), oxoproline (192 to $320 \%$ ), citrulline (480 and $446 \%$ ), lysine (429\% to $677 \%$ ) and methionine (208 to $264 \%$ ).

All treatments induced the concentration of following acids: citric, alpha ketoglutaric, maleic, ribonic, oxalic, 2-deoxytetronic, lactic and idonic acid. The HA reduce the concentration of four organic acids (pyruvic acid -61\%; itaconic -50\%, mucic acid -47\% and succinic acid, $23 \%$ ) and enhance the concentration of saccharic acid and isocitric lactone; PGPB decrease the concentration of only succinic acid $(-27 \%)$ and no organic acids significantly decreased in respect to control in HA+PGPB treatment. The inoculation enhanced the acids 2hydroxyglutaric, aminomalonic, gluconic acid lactone, isothreonic, itaconic, mannonic, mucic

211 and pantothenic. The acids pyruvic (29\%), fumaric acid (126\%), 2-oxogluconic acid (730\%),

212 hexuronic acid (305\%), ascorbic acid (368\%), 3-hydroxypropionic acid (87\%), 2-hydroxyadipic 213 acid (292\%) were found in higher concentration in respect to control plants in the PGPB+HA 214 treatment.

\section{Nitrogenous compounds (Table 4)}

The nucleosides were the most nitrogenous compounds other than amino acids produce in

217 large amount. Adenine was induced by all treatments and as also others nitrogenous compounds 218 like ethanolamine, putrescine and N-acetyl-D-hexosamine. The HA treatments reduce the 219 concentration of thymide $(-56 \%)$ while enhance 4-hydroxyquinoline-2-carboxylic acid $(+650 \%)$, 220 1,3-diaminopropane (+131\%), 2-deoxyadenosine $(+736 \%)$. The PGPB enhance 2221 deoxyguanosine $(+1179 \%)$, adenine $(+3817 \%)$, guanine $(+777 \%)$ and cytosin $(368 \%)$, 222 butirolactan $(+800 \%)$, isonicotic acid $(+260 \%)$, thymidine $(+125 \%)$, thymine $(216 \%)$ and 
223 uracil $(+213 \%)$, while PGPB + HA induce the carnitine $(+384 \%)$, maleimide $(+527 \%)$, orotic

224 acid $(+214 \%)$, spermidine $(+749 \%)$, and 5'-deoxy-5'-methylthioadenosine $(+157 \%)$.

225

226

227

228

229

230

231

232

233

234

235

236

237

238

239

240

241

242

243

244

245

246

247

248

249

\section{Lipids (Table 5)}

Four lipids were inhibited by HA in respect to control including the fatty acids palmitic, 2-monoolein and 6-hydroxycaproate and the plant sterol phytol while monoolein was inhibit by PGPB+HA. The 2-monoolein, lauric, methlylhexadecanoic and perlagonic acids and $\beta$ sistosterol were found in larger concentration in all treatments. The 6-hydroxycaproate dimer, dihydrosphingosine, 2-monoolein and palmitic acid were enhanced by inoculation while monoolein, behenic acid, eicosanoic and capric acid and cholesterol by HA. The following lipids were found in larger concentration only in PGPB+HA treatment: 2-monopalmiitn,1monopalmiteolin, cerotic acid, linoleic mand linolenic acid, myristic acid, palmitoleic acid, pimelic acid, and the plant sterols phytol and the terpene squalene.

\section{Aromatic compounds (Table 6)}

Two aromatics compounds decrease its concentration (pipecoluc acid and coniferin) due HA treatment while PGPB+HA reduce the level of 4-hydroxycinnamic acid. The concentration of shikimic acid, caffeic acid, 3,4-hydroxybenzoic acid and 2,3-dihydroxybenzoic acid were enhanced by all treatments. The inoculation induces the following compounds: chlorogenic, pipecolic and phtahlic acid while HA enhance the concentration of arbutin and 4hydroxycinnamic acid. The PGPB+HA enhance the concentration of parabanic acid, 4hydroxybenzoate, 4-hydroxybenzaldehyde and coniferin.

\section{Multivariate analysis}

The Figure 2 shown the linear combination of original variables. The two first principal components captured $95 \%$ of total variance. As the principal components are orthogonal, it was possible to observe the relationship among the treatments and variables by the scores and loading graphics (Figure 2). The first principal component captured $73 \%$ of total variance and separated PGPB + HA from other treatments while PC2 captured $22 \%$ of total variance and grouped HA and $\mathrm{PGPB}+\mathrm{HA}$ treatments. The main compounds responsible for segregate PGPB $+\mathrm{HA}$ from others 
250 in PC1 were those from lipids metabolism while the changes on shikimic pathway put together 251 HA and $\mathrm{HA}+\mathrm{PGPB}$ treatments in $\mathrm{PC} 2$ axis.

252

253

254

255

256

257

258

259

260

261

262

263

264

265

266

267

268

269

270

271

272

273

274

275

276

277

278

\section{Discussion}

The CG-MS TOF is one of most powerful tools for metabolomics approach and allows the compounds identification about five-fold than sugarcane metabolomics previously reported by Glassop et al., (2007). The effect of treatment on sugarcane leaf metabolites concentration will be discussed considering the main biochemical class of compounds and then an integrate view is presented (Figure 3).

The glucose and glucose-1-P concentrations increase in response of inoculation in comparison with controls plant. Glucose-1-P is a key intermediate in several major carbon anabolic fluxes, such as sucrose, starch and cellulose biosynthesis while Glucose-6-P was found in higher concentration only in $\mathrm{PGPB}+\mathrm{HA}$ showing effect on oxidative pentose phosphate cycle. Therefore, we observed enhance of erythritol in $\mathrm{PGBP}+\mathrm{HA}$ treatment. Erythritol is an important nutrient for $\mathrm{N}_{2}$-fixing plant endosymbionts and larger concentration of fructose-1-P is compatible with the erythritol biosynthesis (Barbier et al., 2014). Lactobionic acid, a disaccharide formed from gluconic acid and galactose was induced by inoculation and may be formed also by oxidation of lactose. Galactose is a member of the raffinose family of oligosaccharides and is the major carbohydrate translocated in many plants. High free concentration of galactose is toxic in leaves reducing cell wall loosening (Cheung and Cleland, 1991). The inhibition of $\beta$ galactosidases release galactose from cell wall polysaccharides and could occurs as growth response induced by auxins (Thorpe et al., 1999). It is well documented that HA and PGPB have auxin-like activity. It was also found high level of lactose and lactobionic acid and this former compound were associate to the metabolic signature related to high plant growth rate in Arabidopsis by Meyer et al., (2007).

The effect of inoculation on plant carbohydrates was accentuated. In Gram negative bacteria, the inner core oligosaccharide typically contains residues of heptose (Kosma, 2009). The role of oligoliposaccharides in bacteria-host interaction is well known and described (Nwodo et al., 2012) and we found a huge increase of glycerol gluco heptose in plants treated with PGPB+HA. Other characteristic from the intensification of carbohydrate metabolism by 
279 inoculation was the increase on aditols concentration in respect to control-plants (e.g., glucicol, 280 ribitol, desoxypentiol, erythritol, Table 1). The alditols are products of photosynthesis and are 281 more reduced their corresponding sugars revealing metabolic boost induced by inoculation. 282 Other intense change on carbohydrate profile includes the production of osmoregulators 283 compounds and sugars linked to cell wall rigidity. Melibiose, galactose, salicin and trehalose 284 were previously described that their concentration enhances under abiotic or biotic stress (Peña 285 et al., 2004). The larger concentration of mannose is compatible with high levels of galactose 286 (Herold and Lewis, 1977). All treatments showed larger levels of salicin or 2-(hydroxymethyl) 287 phenyl-O- $\beta$-D-glucopyranoside, one phenolic glycoside precursor of salicylic acid that have 288 important roles in the ecological survival of plants against biotic and abiotic stress (Mahdi, 289 2014). Finally, it was founded higher levels of hexosamines a precursor of the synthesis of 290 several lipids. It is not surprising, therefore, to find changes on lipids profile induced by 291 inoculation. In addition, as nitrogen metabolism is closely linked to carbohydrates synthesis, the 292 amino acid profile was dramatically changed by the treatments compared with control. The 293 general effect of HA was the decrease in the concentration of most of amino acids in respect to 294 control (Figure 1). On the other hand, the cell concentration of acid amino acids was increased 295 by PGPB including glutamine, asparagine and aspartic acid, the most abundant amino acids in 296 leaves. The accurate determination of amino acids concentrations in the metabolome studies is a 297 tricky question due massive number of compounds and some chemical transformation that may 298 occur during the derivatization process. For instance, glutamine and glutamate can be partially converted to pyroglutamate during derivatization procedures as demonstrated by Kanani and 300 Klapa (2007) and Purwaha et al., (2014). However, we use in this work the data correction for such biases changes developed by platform of primary metabolism identification from Genome Center (UC-Davis, USA) which considers these possible changes (Niehaus et al., 2017). noticed in all bacteria treatments that provides carbon skeleton for ammonium assimilation and biosynthesis of amino acids through the GS/GOGAT nitrogen assimilation pathway (EC 6.3.1.2 and EC 1.4.1.14, respectively). GS catalyzes the ATP-dependent assimilation of $\mathrm{NH}_{4}^{+}$into

307 glutamine, using glutamate as a substrate, and it functions in a cycle with GOGAT 308 (glutamine-2-oxoglutarate aminotransferase), which catalyzes the reductive transfer of the amide group from glutamine to $\alpha$-ketoglutarate (2-oxoglutarate), forming two molecules of glutamate 
310 (Richards et al., 2010). Modulation of GS activity in sugarcane leaves have been demonstrated

311 by inoculation with diazotrophic bacteria and explain partially nitrogen fixation abilities

312 associated with sugarcane genotypes (de Matos Nogueira et al., 2005). In addition, changes in

313 amino acid pools were previous demonstrated on sugarcane plants inoculated with diazotrophic

314 bacteria that modulates nitrogen fixation and ammonium release by the bacteria (Loiret et al., 315 2009).

316 The proline and oxoproline concentration was larger in inoculate treatments and the role 317 of these amino acids in cell osmoregulation is well documented. The biotic stress induced by 318 inoculation can promote a general plant response that includes increase of 5-hydroxy norvaline 319 production and citrulline (Yokota et al., 2002). A general view, plant inoculation sparks amino 320 acids production especially that related to urea cycle (ornithine cycle). The 5-aminovaleric acid, 321 isoleucine and proline were induced by HA. In plants, stress initiates a signal-transduction 322 pathway, in which increased cytosolic $\mathrm{Ca}^{2+}$ activates $\mathrm{Ca}^{2+} /$ calmodulin-dependent glutamate 323 decarboxylase activity and GABA synthesis. Elevated $\mathrm{H}^{+}$and substrate levels can also stimulate 324 glutamate decarboxylase activity. GABA accumulation probably is mediated primarily by 325 glutamate decarboxylase (Shelp et al., 1999). Ramos et al., (2015) describe a mechanism 326 involved $\mathrm{Ca}^{2+}$ pulse uptake by plants stimulated by HA and describe a dynamic interaction 327 between $\mathrm{Ca}^{2+} / \mathrm{H}^{+}$efflux-influx as well as the induction on CDPK (calcium dependent 328 phosphokinase) activity and $\mathrm{Ca}^{2+}$ channels. Furthermore, sugarcane transcriptomic study showed 329 that protein kinases are main genetic response against drought and $\mathrm{N}_{2}$-fixing inoculation (Rocha 330 et al., 2007). It is possible conclude based in metabolic profile analysis that the treatments 331 improve the mechanism of adaptation based on ornithine cycle.

333 possible to observe a significant enhance on nucleoside concentration (Table 2 and 4). The 334 interdependence of threonine, methionine and isoleucine metabolism in plants is well described 335 Joshi et al., (2010). Isoleucine is synthesized from threonine and methionine, which are derived 336 from aspartate via enzymes located in the plastids and homoserine kinase (EC 2.7.1.39), which 337 catalyzes the formation of O-phosphohomoserine from homoserine, leads to the formation of 338 either threonine or methionine (Hildebrandt et al., 2015). PGPB and PGPB+HA enhance both 339 the homoserine and isoleucine concentration. 
The basic components of the citric acid cycle have their concentration enhanced by the

341

342

343

344

345

346

347

348

349

350

351

352

353

354

355

356

357

358

359

360

361

362

363

364

365

366

367

368 treatments including oxalic, citric and $\alpha$-ketoglutaric acid while succinic and fumaric acids decreased in respect to control (Table 3). High amount of $\alpha$-keto glutaric acid results in higher concentration of glutaric acid and the glutamate/glutamine synthesis. This is coherent with increase of ornithine, citrulline and proline and oxoproline production in plants inoculated. Another important evidence is the higher concentration of polyamines a direct product from ornithine transformation. Several intermediary products of TCA pathways were accumulated in higher concentration including dihydroxymalonic acid, isocitric lactone, 2-oxogluconic acid, succinate semialdehyde. Ascorbic acid was found in high concentration. Ascorbate is a major metabolite in plants. It is an antioxidant and, in association with other components of the antioxidant system, protects plants against oxidative damage resulting from aerobic metabolism, photosynthesis and a range of pollutants (Colville and Smirnoff, 2008). This increase is compatible with enhance of glucoronate metabolism observed (Table 3) and galactonic, gluconic, gluconic acid lactone, glutaric and glycolic acid concentration since a biosynthetic pathway of ascorbic acid via GDP-mannose, GDP-L-galactose, L-galactose, and L-galactono1,4-lactone has been proposed (Smirnoff, 1996). Pantothenic acid also was induced by inoculation and is a water-soluble vitamin (vitamin B5) essential for the synthesis of CoA and ACP, cofactor in energy yielding reactions including carbohydrate metabolism and fatty acid synthesis (Coxon et al., 2005).

Nucleoside and nucleoside derivatives (cytosine, guanine, adenine and thymine) participate in the bioenergetics process (ATP) and macromolecules synthesis including polysaccharides, phospholipids and glycolipids. The nucleosides synthesis was stimulated by treatments (Table 4). The growth cell acceleration must be preceded by carbohydrates metabolism and by the units necessary to build cell nuclei. The enhance of inosine concentration was observed in HA treatment. This compound is linked to cell growth activation. Furthermore, it was previously observed enhance of root growth of different plants with exogenous use of inosine (Tokuhisa et al., 2010). The HA like cytokinin activity was previously described (Mora et al., 2012) and the precursors of cytokinin was increased by HA treatment (3-hidroxyimethyl glutaric acid, oxoadenosine and inosine). Ethanolamine is a serine derivative (Rontein et al., 
369 2001) and substrate to choline synthesis and phosphatydiletanolamine and phosphadidilcoline the 370 main lipids in plant cell membranes.

The lipids metabolism was strongly affected by PGPB and responsible for the main 372 differentiation among the other treatments according PCA analysis (Figure 2, Table 5). The 373 cytosine and 2-deoxyguanosine were huge increased with PGPB inoculation. The butyrolactam 374 is synthesized from GABA cyclization by GABA-cysteine hydrogenase. This pathway may have 375 been active by PGPB due the presence of high concentration of oxoproline. This amino acid is 376 synthesized using glutamine-cysteine by cyclization catalyzed by (glutamiltransferase, EC 377 2.3.2.4) producing cysteine and oxoproline. This pathway was previously described in rice as 378 response to Xanthomonas infection (Sana et al., 2010). In the treatment with PGPB+HA one 379 imide (maleimide) was found in high concentration and it is a well-known cytotoxic compound.

380 The main effect of maleimide is block the vesicular transport mainly galactose transport 381 (Uemura et al., 2004). Spermidine and putrescine were found in high concentration with PGPB 382 and PGPB $+\mathrm{HA}$ and are involved in cell growth inducing root growth and normally detected in 383 high concentration in active tissue under stress (Takahashi and Kakehi, 2009). Previous report 384 compares the action of HA with polyamines (Young and Chen, 1997; Mora et al., 2012). Larger

385

386

387

388

389

390

391

392

393

394

395

396

397

398 concentration of isonicotinic acid was found in $\mathrm{PGPB}+\mathrm{HA}$ treatment as well as the orotic acid a precursor for the synthesis of water soluble B13 vitamin. The vitamins have important role in cell redox status and are enzymatic cofactor of metabolic reaction (Asensi-Fabado and MunnéBosch, 2010).

The enhance of a range of cytosolic metabolites including glucose 6-P, malate derivatives, phosphoenolpyruvate and pyruvate support high rates of fatty acid synthesis by inoculated plants (Pleite et al., 2005). The long chain fatty acids as docosanoic acid (behenic acid), 2-monolein and hexadecanol were found in high concentration in HA treated plants. These long chain lipids are involved in membrane structure and dynamics regulating cell size but also the division and differentiation process (Zheng et al., 2005). Sphingolipids were found in larger concentration in $\mathrm{HA}$ and $\mathrm{HA}+\mathrm{PGPB}$ plants. Elevated levels of complex sphingolipids were associated with cell apoptosis, terminal differentiation, or cell cycle arrest (Du Granrut and Cacas, 2016). In another way the decrease on sphingolipids levels can lead to cell proliferation increase (Bach and Faure, 2010). 
Sterols are synthesized by the mevalonate pathway and was possible to observe enhance of

400

401

402

403

404

405

406

407

408

409

410

411

412

413

414

415

416

417

418

419

420

421

422

423

424

425

426

427

428

sterols concentration induced by treatments in respect to control. $\beta$-sitosterol is the main plant sterols involved into cellulose elongation chain and its increase were observed in HA and HA+PGPB treatments. Tocopherol is a precursor of main lipids soluble vitamin (vitamin E) and its concentration is regulated by biotic and abiotic stress (Munne-Bosch, 2005). The cholesterol concentration is often low in cell plants but the GC-MS TOF was sensible to detect significant variation in its concentration according the treatments. Phytol was abundant in HA+PGPB treatment and is the main precursor to brassinosteroids synthesis. Other lipid in abundance in $\mathrm{HA}+\mathrm{PGPB}$ was the terpene squalene $(\mathrm{C} 30 \mathrm{H} 50)$ precursor from major plant sterols (Amarowicz, 2009). The azelaic acid is a dicarboxylic acid with nine carbons and in the plant synthesis the even-numbered chains are privileged due acetyl-coA mechanism reactions. This fatty acid was present only in PGPB and HA+PGPB treatments. Previously it was found enhance in azelaic acid concentration in Arabidopsis infected by Pseudomonas syringe starting the plant defense against pathogen by activation of salicylic acid pathway (Jung et al., 2009).

In plants, the biosynthesis of isoprene units and common precursors for isoprenoid biosynthesis involves two distinct pathways. According (Hemmerlin et al., 2006), the mevalonate (MVA) is utilized for the biosynthesis of non-plastidial isoprenoids (phytosterols, prenylated proteins, sesquiterpenoids), whereas plastidial isoprenoids (carotenoids, plastoquinone, diterpenes, monoterpenes, etc.) are synthesized via the alternative 2C-methyl-Derythritol 4-phosphate (MEP) pathway. This pathway uses 1-Deoxy-D-xylulose 5-phosphate synthase (DXS) and thiamine to produce isoprenoids. We identify a significant enhance in the xylulose $(+1263 \%)$ as well in the thymine $(+4970 \%)$ concentration in a clear indicative of isoprenoids pathways stimulation by PGPB. Isoprenoids, represent the chemically and functionally most diversified class compounds including electron carriers (quinones), membrane constituents (sterols), vitamins (A, D, E and K), plant hormones (side chain of cytokinin, abscisic acid, gibberellins and brassinosteroids), and photosynthetic pigments (chlorophyll, phytol and carotenoids) (Hemmerlin et al., 2006). In fact, we observe an increase of $p$-hydroquinone, several sterols ( $\beta$-sitosterol) phytol, tocopherol, stigmasterol, cholesterol) cytosine, inosine and squalene in sugarcane treated with PGPB+HA. Furthermore, the accumulation of methylerytrol not discharge the enhance of isoprenoids products using a non-mevalonate pathway (MEP/DOXP) 
429 that use 2-methyl-D-erythritol 4-phosphate (MEP) and deoxy-xylulose 5 phosphate (DOXP) 430 rote.

The shikimic pathway was also staggeringly changed by inoculation. Phenylpropanoids 432 are a class of phenylalanine derivatives with a basic C6-C3 (phenyl-propane) skeleton (Iriti and 433 Faoro, 2009). In turn, the essential amino acid phenylalanine arises from the shikimate pathway, 434 as well as the other aromatic amino acids tyrosine and tryptophan. Precursors of this pathway are 435 phosphoenolpyruvate, from glycolysis, and erythrose 4-phosphate from pentose phosphate (Tzin 436 and Galili, 2010). Both compounds were its concentration enhanced by the treatments. 437 Enolpiruvate enhance 22\%, 85\% and 246\% with HA, PGPB and PGPB+HA treatment, 438 respectively in respect to control while several derivatives of erytrose were found (erythritol, 439 erythronic acid lactone, erythrose) in increased amount in inoculated plants. Than we expected 440 an influence on phenylpropanoids compounds and it was confirmed by influence on multivariate 441 analysis (PCA2, Figure 3). The first step to shikimic branch pathway is the accumulation of 442 aromatic amino acids. It was also observed an increase of phenylalanine concentration and 443 consequently the production of hydroxyl cinnamic derivatives. The main aromatic compounds 444 induced by PGPB are derivatives of phenyl propanoids units as ferulic acids. The enhance of 445 concentration on aromatics compound is often associated to improve redox status and 446 antioxidative cell protection. Phenylalanine (tyrosine) ammonia-lyase (PAL/TAL; EC 4.3.1.5) 447 catalyzes the first committed step in the biosynthesis of phenolics by converting phenylalanine to 448 trans-cinnamic acid and tyrosine to p-coumaric acid. Phenylalanine usually is the preferred 449 substrate, but the monocot enzyme can use both phenylalanine and tyrosine. (Schiavon et al., 450 2010) observed enhance of PAL/TAL expression in maize treated with HA and therein the 451 concentration of total phenolic compounds. Here we provide an extensive list of aromatic 452 compounds induce by HA. However, as the enhanced promoted in aromatic amino acids 453 phenylalanine and tyrosine by PGPB and PGPB+HA was larger is expected increase on aromatic 454 moieties. Actually, a number of hydroxybenzoic acid were found including a direct derivative of 455 salicylic acids like gentisic or quinic acids (caffeic acids) both involved in plant disease 456 resistance. The improvement on the aromatic compounds synthesis induced by endophytic 457 bacteria inoculation was previously related in sugarcane (França et al., 2001).

\section{Conclusion}


Here we describe the changes in the metabolite profile in sugarcane inoculated with

460

461

462

463

464

465

466

467

468

469

470

471

472

473

474

475

476

477

478

479

480

481

482

483

484

485

486

487

488

489

490

491

492 PGPB and HA. The glycolysis pathway was activated with high production of glycolysis and derivatives providing substrate to pentose pathway and tricarboxylic acid cycle. The erithroses and heptuloses provide substrate do xylose and ribose synthesis and the nucleotides and acid shikimic acids was improved as well as the mevalonate pathway with enhance of phytosterols. The sugar aminoacids were found in larger concentration as well as sphingolipids. Tricarboxylic acid cycle improvement also provides sources for lipids and amino acid metabolism the main routes changed by inoculation. The cell growth acceleration was compatible with high nucleosides synthesis as well as water and lipid soluble vitamins. In general, a several compounds that as an anti-oxidative agent and osmoprotectors were produced in inoculated plants showing a rapid metabolic response to infection. Particularly, the treatment with HA decrease the number of compounds with high cellular levels. This is compatible with previous proteome (Carletti et al., 2008) and transcriptome (Trevisan et al., 2011) studies that reported inhibition of differential expression for both protein and genes in response of HA. The HA increase the metabolic response of inoculation with PGPB. The levels of glucuronic acids and threonic acids increased when plant was inoculated by PGPB+HA. Finally, analytical results obtained using GC-TOF MS clearly demonstrated the enhance of TCA activity showing accumulation of $\alpha$-Ketoglutaric acid a central metabolic substrate to glutamine and glutamic acid synthesis precursor of amino acids ornithine, citrulline, proline, oxoproline, hydroxynorvaline and the polyamines (spermidine and putrescine). The level of fatty acids as strongly modified by PGPB+HA.

\section{References}

Aguiar, N.O., Medici, L., Olivares, F., Dobbss, L., Torres-Netto, A., Silva, S., Novotny, E., and Canellas, L. (2016). Metabolic profile and antioxidant responses during drought stress recovery in sugarcane treated with humic acids and endophytic diazotrophic bacteria. Annals of applied biology 168, 203-213.

Aguiar, N.O., Olivares, F.L., Novotny, E.H., Dobbss, L.B., Balmori, D.M., Santos-Júnior, L.G., Chagas, J.G., Façanha, A.R., and Canellas, L.P. (2013). Bioactivity of humic acids isolated from vermicomposts at different maturation stages. Plant and soil 362, 161-174.

Alves, B. J., Boddey, R. M., and Urquiaga, S. (2003). The success of BNF in soybean in Brazil. Plant and soil, 252, 1-9.

Amarowicz, R. (2009). Squalene: A natural antioxidant? European journal of lipid science and technology 111, 411-412. 
493

494

495

496

497

498

499

500

501

502

503

504

505

506

507

508

509

510

511

512

513

514

515

516

517

518

519

520

521

522

523

524

525

526

527

528

529

530

531

532

533

534

535

536

537
Asensi-Fabado, M.A., and Munné-Bosch, S. (2010). Vitamins in plants: occurrence, biosynthesis and antioxidant function. Trends in plant science 15, 582-592.

Bach, L., and Faure, J.D. (2010). Role of very-long-chain fatty acids in plant development, when chain length does matter. Comptes Rendus Biologies 333, 361-370.

Baldani, J.I., Reis, V.M., Videira, S.S., Boddey, L.H., and Baldani, V.L.D. (2014). The art of isolating nitrogen-fixing bacteria from non-leguminous plants using $\mathrm{N}$-free semi-solid media: a practical guide for microbiologists. Plant and soil 384, 413-431.

Barbier, T., Collard, F., Zúñiga-Ripa, A., Moriyón, I., Godard, T., Becker, J., Wittmann, C., Van Schaftingen, E., and Letesson, J.-J. (2014). Erythritol feeds the pentose phosphate pathway via three new isomerases leading to D-erythrose-4-phosphate in Brucella. Proceedings of the National Academy of Sciences 111, 17815-17820.

Bertalan, M., Albano, R., de Pádua, V., Rouws, L., Rojas, C., Hemerly, A., ... \& França, L. (2009). Complete genome sequence of the sugarcane nitrogen-fixing endophyte Gluconacetobacter diazotrophicus Pal5. BMC genomics, 10(1), 450.

Bhattacharyya, P.N., and Jha, D.K. (2012). Plant growth-promoting rhizobacteria (PGPR): emergence in agriculture. World Journal of Microbiology \& Biotechnology 28, 13271350.

Carletti, P., Masi, A., Spolaore, B., De Laureto, P.P., De Zorzi, M., Turetta, L., Ferretti, M., and Nardi, S. (2008). Protein expression changes in maize roots in response to humic substances. Journal of chemical ecology 34, 804.

Carvalho, T.L., Pires, E., Saraiva, R., Vargas, L., Bomfim, A.C.J., Ballesteros, H., Baldani, J.I., Ferreira, P.C., and Hemerly, A.S. (2014). "Nitrogen fixation in grasses-gluconacetobacter activates genes in sugarcane", in: BMC Proceedings: BioMed Central), O20.

Cavalcante, V.A., and Dobereiner, J. (1988). A new acid-tolerant nitrogen-fixing bacterium associated with sugarcane. Plant and soil 108, 23-31.

Cheung, S.P., and Cleland, R.E. (1991). Galactose inhibits auxin-induced growth of Avena coleoptiles by two mechanisms. Plant and cell physiology 32, 1015-1019.

Claessen, M.E.C., Barreto, W.D.O., Paula, J.D., and Duarte, M.N. (1997). "Manual de métodos de análise de solo". Rio de Janeiro: Embrapa-CNPS).

Colville, L., and Smirnoff, N. (2008). Antioxidant status, peroxidase activity, and PR protein transcript levels in ascorbate-deficient Arabidopsis thaliana vtc mutants. Journal of Experimental Botany 59, 3857-3868.

Coxon, K., Chakauya, E., Ottenhof, H., Whitney, H., Blundell, T., Abell, C., and Smith, A. (2005). "Pantothenate biosynthesis in higher plants". Portland Press Limited).

Da Silva, S.F., Olivares, F.L., and Canellas, L.P. (2017). The biostimulant manufactured using diazotrophic endophytic bacteria and humates is effective to increase sugarcane yield. Chemical and Biological Technologies in Agriculture 4, 24.

De Matos Nogueira, E., Olivares, F.L., Japiassu, J.C., Vilar, C., Vinagre, F., Baldani, J.I., and Hemerly, A.S. (2005). Characterization of glutamine synthetase genes in sugarcane genotypes with different rates of biological nitrogen fixation. Plant Science 169, 819-832.

Du Granrut, A.D.B., and Cacas, J.-L. (2016). How very-long-chain fatty acids could signal stressful conditions in plants? Frontiers in plant science 7.

Fiehn, O., Wohlgemuth, G., and Scholz, M. (2005). "Setup and annotation of metabolomic experiments by integrating biological and mass spectrometric metadata", in: Data integration in the life sciences: Springer), 735-735. 
538

539

540

541

542

543

544

545

546

547

548

549

550

551

552

553

554

555

556

557

558

559

560

561

562

563

564

565

566

567

568

569

570

571

572

573

574

575

576

577

578

579

580

581

582

583

Fiehn, O., Wohlgemuth, G., Scholz, M., Kind, T., Lee Do, Y., Lu, Y., Moon, S., and Nikolau, B. (2008). Quality control for plant metabolomics: reporting MSI-compliant studies. Plant J 53, 691-704.

França, S., Roberto, P., Marins, M., Puga, R., Rodrigues, A., and Pereira, J. (2001). Biosynthesis of secondary metabolites in sugarcane. Genetics and molecular biology 24, 243-250.

Glassop, D., Roessner, U., Bacic, A., and Bonnett, G.D. (2007). Changes in the sugarcane metabolome with stem development. Are they related to sucrose accumulation?

Hemmerlin, A., Tritsch, D., Hartmann, M., Pacaud, K., Hoeffler, J.F., Van Dorsselaer, A., Rohmer, M., and Bach, T.J. (2006). A cytosolic arabidopsis D-xylulose kinase catalyzes the phosphorylation of 1-deoxy-D-xylulose into a precursor of the plastidial isoprenoid pathway. Plant Physiology 142, 441-457.

Herold, A., and Lewis, D. (1977). Mannose and green plants: occurrence, physiology and metabolism, and use as a tool to study the role of orthophosphate. New Phytologist 79, 140.

Hildebrandt, T.M., Nesi, A.N., Araújo, W.L., and Braun, H.-P. (2015). Amino acid catabolism in plants. Molecular plant 8, 1563-1579.

Hong, J., Yang, L., Zhang, D., \& Shi, J. (2016). Plant metabolomics: an indispensable system biology tool for plant science. International journal of molecular sciences, 17(6), 767.

Iriti, M., and Faoro, F. (2009). Chemical diversity and defence metabolism: how plants cope with pathogens and ozone pollution. International journal of molecular sciences 10, 33713399.

Joshi, V., Joung, J.-G., Fei, Z., and Jander, G. (2010). Interdependence of threonine, methionine and isoleucine metabolism in plants: accumulation and transcriptional regulation under abiotic stress. Amino acids 39, 933-947.

Jung, H.W., Tschaplinski, T.J., Wang, L., Glazebrook, J., and Greenberg, J.T. (2009). Priming in systemic plant immunity. Science 324, 89-91.

Kanani, H. H., and Klapa, M. I. (2007). Data correction strategy for metabolomics analysis using gas chromatography-mass spectrometry. Metabolic engineering, 9(1), 39-51.

Kind, T., Wohlgemuth, G., Lee, D.Y., Lu, Y., Palazoglu, M., Shahbaz, S., and Fiehn, O. (2009). FiehnLib: mass spectral and retention index libraries for metabolomics based on quadrupole and time-of-flight gas chromatography/mass spectrometry. Analytical chemistry 81, 10038-10048.

Kosma, P. (2009). Chemical synthesis of the core oligosaccharide of bacterial lipopolysaccharide. Elsevier: London.

Lee, D.Y., and Fiehn, O. (2008). High quality metabolomic data for Chlamydomonas reinhardtii. Plant methods 4, 7.

Loiret, F.G., Grimm, B., Hajirezaei, M.R., Kleiner, D., and Ortega, E. (2009). Inoculation of sugarcane with Pantoea sp increases amino acid contents in shoot tissues; serine, alanine, glutamine and asparagine permit concomitantly ammonium excretion and nitrogenase activity of the bacterium. Journal of Plant Physiology 166, 1152-1161.

Mahdi, J.G. (2014). Biosynthesis and metabolism of $\beta$-D-salicin: A novel molecule that exerts biological function in humans and plants. Biotechnology Reports 4, 73-79.

Meyer, R.C., Steinfath, M., Lisec, J., Becher, M., Witucka-Wall, H., Törjék, O., Fiehn, O., Eckardt, Ä., Willmitzer, L., and Selbig, J. (2007). The metabolic signature related to high plant growth rate in Arabidopsis thaliana. Proceedings of the National Academy of Sciences 104, 4759-4764. 
584

585

586

587

588

589

590

591

592

593

594

595

596

597

598

599

600

601

602

603

604

605

606

607

608

609

610

611

612

613

614

615

616

617

618

619

620

621

622

623

624

625

626

627

628

629
Mora, V., Baigorri, R., Bacaicoa, E., Zamarreño, A.M., and García-Mina, J.M. (2012). The humic acid-induced changes in the root concentration of nitric oxide, IAA and ethylene do not explain the changes in root architecture caused by humic acid in cucumber. Environmental and experimental botany 76, 24-32.

Munne-Bosch, S. (2005). The role of $\alpha$-tocopherol in plant stress tolerance. Journal of plant physiology 162, 743-748.

Niehaus, T. D., Elbadawi-Sidhu, M., de Crécy-Lagard, V., Fiehn, O., \& Hanson, A. D. (2017). Discovery of a widespread prokaryotic 5-oxoprolinase that was hiding in plain sight. Journal of Biological Chemistry, 292(39), 16360-16367.

Nwodo, U.U., Green, E., and Okoh, A.I. (2012). Bacterial Exopolysaccharides: Functionality and Prospects. International Journal of Molecular Sciences 13, 14002-14015.

Olivares, F.L., Baldani, V.L., Reis, V.M., Baldani, J.I., and Döbereiner, J. (1996). Occurrence of the endophytic diazotrophs Herbaspirillum spp. in roots, stems, and leaves, predominantly of Gramineae. Biology and Fertility of Soils 21, 197-200.

Olivares, F. L., Busato, J. G., Paula, A. M., Lima, L. S., Aguiar, N. O., \& Canellas, L. P. (2017). Plant growth promoting bacteria and humic substances: crop promotion and mechanisms of action. Chemical and Biological Technologies in Agriculture, 4(1), 30.

Oliveira, A.L.M., Stoffels, M., Schmid, M., Reis, V.M., Baldani, J.I., and Hartmann, A. (2009). Colonization of sugarcane plantlets by mixed inoculations with diazotrophic bacteria. European Journal of Soil Biology 45, 106-113.

Owen, D., Williams, A.P., Griffith, G.W., and Withers, P.J.A. (2015). Use of commercial bioinoculants to increase agricultural production through improved phosphorus acquisition. Applied Soil Ecology 86, 41-54.

Pedrosa, F. O., Monteiro, R. A., Wassem, R., Cruz, L. M., Ayub, R. A., Colauto, N. B., ... \& Madeira, H. M. (2011). Genome of Herbaspirillum seropedicae strain SmR1, a specialized diazotrophic endophyte of tropical grasses. PLoS genetics, 7(5), e1002064.

Peña, M.J., Ryden, P., Madson, M., Smith, A.C., and Carpita, N.C. (2004). The galactose residues of xyloglucan are essential to maintain mechanical strength of the primary cell walls in Arabidopsis during growth. Plant Physiology 134, 443-451.

Pleite, R., Pike, M.J., Garcés, R., Martínez-Force, E., and Rawsthorne, S. (2005). The sources of carbon and reducing power for fatty acid synthesis in the heterotrophic plastids of developing sunflower (Helianthus annuus L.) embryos. Journal of Experimental Botany 56, 1297-1303.

Purwaha, P., Silva, L. P., Hawke, D. H., Weinstein, J. N., \& Lorenzi, P. L. (2014). An artifact in LC-MS/MS measurement of glutamine and glutamic acid: in-source cyclization to pyroglutamic acid. Analytical chemistry, 86(12), 5633-5637.

Ramos, A.C., Dobbss, L.B., Santos, L.A., Fernandes, M.S., Olivares, F.L., Aguiar, N.O., and Canellas, L.P. (2015). Humic matter elicits proton and calcium fluxes and signaling dependent on $\mathrm{Ca}^{2+}$-dependent protein kinase (CDPK) at early stages of lateral plant root development. Chemical and Biological Technologies in Agriculture 2, 3.

Reis, V. M., de Oliveira, A. L. M., da Silva, M. F., Olivares, F. L., Baldani, J. I., Boddey, R. M., \& Urquiaga, S. (2008). Inoculants for Sugar Cane: The Scientific Bases for the Adoption of the Technology for Biofuel Production. In Biological Nitrogen Fixation: Towards Poverty Alleviation through Sustainable Agriculture (pp. 67-68). Springer, Dordrecht.

Richards, N.G., Humkey, R.N., Li, K., Meyer, M.E., and De Sintjago, T.C.C. 8.06-Tunnels and Intermediates in the Glutamine-Dependent Amidotransferases. 
630 Rocha, F.R., Papini-Terzi, F.S., Nishiyama, M.Y., Vêncio, R.Z., Vicentini, R., Duarte, R.D., De

631

632

633

634

635

636

637

638

639

640

641

642

643

644

645

646

647

648

649

650

651

652

653

654

655

656

657

658

659

660

661

662

663

664

665

666

667

668

669

670

671

672

673

674 Rosa, V.E., Vinagre, F., Barsalobres, C., and Medeiros, A.H. (2007). Signal transductionrelated responses to phytohormones and environmental challenges in sugarcane. $B M C$ genomics 8, 71 .

Rontein, D., Nishida, I., Tashiro, G., Yoshioka, K., Wu, W.-I., Voelker, D.R., Basset, G., and Hanson, A.D. (2001). Plants synthesize ethanolamine by direct decarboxylation of serine using a pyridoxal phosphate enzyme. Journal of Biological Chemistry 276, 35523-35529.

Sana, T.R., Fischer, S., Wohlgemuth, G., Katrekar, A., Jung, K.H., Ronald, P.C., and Fiehn, O. (2010). Metabolomic and transcriptomic analysis of the rice response to the bacterial blight pathogen Xanthomonas oryzae pv. oryzae. Metabolomics 6, 451-465.

Schiavon, M., Pizzeghello, D., Muscolo, A., Vaccaro, S., Francioso, O., and Nardi, S. (2010). High molecular size humic substances enhance phenylpropanoid metabolism in maize (Zea mays L.). Journal of chemical ecology 36, 662-669.

Scholz, M., and Fiehn, O. (2007). "SetupX--a public study design database for metabolomic projects", in: Pacific Symposium on Biocomputing. Pacific Symposium on Biocomputing), 169-180.

Schultz, N., Da Silva, J.A., Sousa, J.S., Monteiro, R.C., Oliveira, R.P., Chaves, V.A., Pereira, W., Da Silva, M.F., Baldani, J.I., Boddey, R.M., Reis, V.M., and Urquiaga, S. (2014). Inoculation of Sugarcane with Diazotrophic Bacteria. Revista Brasileira De Ciencia Do Solo 38, 407-414.

Schultz, N., Pereira, W., Reis, V.M., and Urquiaga, S.S. (2016). Produtividade e diluição isotópica de $15 \mathrm{~N}$ em cana-de-açúcar inoculada com bactérias diazotróficas. Pesquisa Agropecuária Brasileira 51, 1594-1601.

Shelp, B.J., Bown, A.W., and Mclean, M.D. (1999). Metabolism and functions of gammaaminobutyric acid. Trends Plant Sci 4, 446-452.

Smirnoff, N. (1996). The function and metabolism of ascorbic acid in plants. Annals of Botany 78, 661-669.

Takahashi, T., and Kakehi, J.-I. (2009). Polyamines: ubiquitous polycations with unique roles in growth and stress responses. Annals of Botany 105, 1-6.

Thorpe, M., Macrae, E., Minchin, P., and Edwards, C. (1999). Galactose stimulation of carbon import into roots is confined to the Poaceae. Journal of experimental botany 50, 16131618.

Tokuhisa, D., Shinano, T., Watanabe, T., Yamamura, T., and Osaki, M. (2010). Promotion of root growth by the application of inosine. Soil Science \& Plant Nutrition 56, 272-280.

Trevisan, S., Botton, A., Vaccaro, S., Vezzaro, A., Quaggiotti, S., and Nardi, S. (2011). Humic substances affect Arabidopsis physiology by altering the expression of genes involved in primary metabolism, growth and development. Environmental and Experimental Botany $74,45-55$.

Tzin, V., and Galili, G. (2010). The biosynthetic pathways for shikimate and aromatic amino acids in Arabidopsis thaliana. The arabidopsis book, $\mathrm{e} 0132$.

Uemura, T., Ueda, T., Ohniwa, R.L., Nakano, A., Takeyasu, K., and Sato, M.H. (2004). Systematic analysis of SNARE molecules in Arabidopsis: dissection of the post-Golgi network in plant cells. Cell structure and function 29, 49-65.

Vassilev, N., Vassileva, M., Lopez, A., Martos, V., Reyes, A., Maksimovic, I., EichlerLobermann, B., and Malusa, E. (2015). Unexploited potential of some biotechnological 
675

676

677

678

679

680

681

682

683

684

685

686

687

688

689

690

691

692

693

694

695

696

697

698

699

700

701

702

703

704

705

706

707

708

709

710

711

712

713

714

715

716

717

718

719

720 techniques for biofertilizer production and formulation. Applied Microbiology and Biotechnology 99, 4983-4996.

Yokota, A., Kawasaki, S., Iwano, M., Nakamura, C., Miyake, C., and Akashi, K. (2002). Citrulline and DRIP-1 protein (ArgE homologue) in drought tolerance of wild watermelon. Annals of Botany 89, 825-832.

Young, C., and Chen, L. (1997). Polyamines in humic acid and their effect on radical growth of lettuce seedlings. Plant and Soil 195, 143-149.

Zheng, H., Rowland, O., and Kunst, L. (2005). Disruptions of the Arabidopsis enoyl-CoA reductase gene reveal an essential role for very-long-chain fatty acid synthesis in cell expansion during plant morphogenesis. The Plant Cell 17, 1467-1481.

Figures Captions 
721

722 Figure 1 - Schematic representation of the effect of the treatments on the levels of amino acids 723 in respect to control. Rectangles containing aminoacids pools that derivates from pathways 724 conversions of 3-phosphoglycerate (PGA), P-enolpyruvate, pyruvate, oxaloacetate and $\alpha$ 725 ketoglutarate. Aminoacids with significant higher values related to control had shown color 726 circles. The color circles represent the treatments (HA: black; PGPB: blue, HA+PGPB: red) and 727 the magnitude of influence of each treatment in respect to control is represented by the circle 728 size.

729 Figure 2 - PCA scores for CG-MS data indicating good separation of treatments in different 730 groups according to inoculation. The loadings and their coefficient weight that indicates the 731 position of the variables along the PCs and consequently their importance for that PC are showed 732 in supplementary file.

733 Figure 3 - Representation of the most important metabolites identified on main sugarcane 734 biochemical pathways. The color squares represent the treatments (HA: black; PGPB: blue, 735 HA+PGPB: red) and the increase of concentration level (\% in respect to control) was ranking 736 according to the color-coded scale bar pointed that range from 100 to $500 \mathrm{x}$ times concentration 737 related to control plants. 


\section{Table $\mathbf{1}$ (on next page)}

Carbohydrates identified on sugarcane methanolic leaves extracts by GC-MS TOF

The treatments were inoculation with $G$. diazotrophicus and $H$. seropedicae (PGPB), bacteria and humic acid (PGPB $+\mathrm{HA})$ or only humic acid $(\mathrm{HA})$ isolated from vermicompost. The data were expressed in respect to control treatment (\%). 
Table 1. Carbohydrates identified on sugarcane methanolic leaves extracts by GC-MS TOF. The treatments were inoculation with $G$. diazotrophicus and $H$. seropedicae (PGPB), bacteria and humic acid (PGPB+HA) or only humic acid (HA) isolated from vermicompost. The data were expressed in respect to control treatment $(\%)$.

\begin{tabular}{|c|c|c|c|}
\hline metabolite & HA & PGPB & PGPB+HA \\
\hline 1,5-anhydroglucitol & $-80^{* *}$ & $-13^{*}$ & $42^{* *}$ \\
\hline 199177 carbohydrate & $58^{\mathrm{ns}}$ & $110^{\text {ns }}$ & $187^{\mathrm{ns}}$ \\
\hline 1-deoxyerythritol & $104^{* *}$ & $1664^{* *}$ & $1231^{* *}$ \\
\hline 1-desoxypentitol & $-28^{\text {ns }}$ & $320^{* *}$ & $897^{* *}$ \\
\hline 1-kestose & $79^{\text {ns }}$ & $25^{\mathrm{ns}}$ & $74^{\mathrm{ns}}$ \\
\hline 200391 disaccharide & $-36^{* *}$ & $8^{\text {ns }}$ & $81^{* *}$ \\
\hline 200509 carbohydrate & $92^{* *}$ & $-4^{\text {ns }}$ & $54^{* *}$ \\
\hline 200658 carbohydrate & $-19^{n s}$ & $28^{\mathrm{ns}}$ & $346^{* *}$ \\
\hline 201952 carbohydrate & $46^{\mathrm{ns}}$ & $24^{\mathrm{ns}}$ & $271^{* *}$ \\
\hline 202573 carbohydrate & $18^{\mathrm{ns}}$ & $-1^{\text {ns }}$ & $871^{* *}$ \\
\hline 202832 disaccharide & $-13^{\mathrm{ns}}$ & $21^{\mathrm{ns}}$ & $49^{* *}$ \\
\hline 208658 carbohydrate & $19^{\text {ns }}$ & $175^{\mathrm{ns}}$ & $779^{\mathrm{ns}}$ \\
\hline 208845 carbohydrate & $-19^{* *}$ & $-27^{* *}$ & $-48^{* *}$ \\
\hline 214402 carbohydrate & $-11^{\text {ns }}$ & $202^{\text {ns }}$ & $120^{\mathrm{ns}}$ \\
\hline 225906 disaccharide & $33^{\mathrm{ns}}$ & $16^{\mathrm{ns}}$ & $83^{\mathrm{ns}}$ \\
\hline 231180 carbohydrate & $61^{\mathrm{ns}}$ & $29^{\text {ns }}$ & $240^{*}$ \\
\hline 231210 disaccharide & $64^{\mathrm{ns}}$ & $79^{\text {ns }}$ & $182^{\mathrm{ns}}$ \\
\hline 233289 carbohydrate & $-19^{n s}$ & $188^{\text {ns }}$ & $911^{* *}$ \\
\hline 238267 trisaccharide & $14^{\mathrm{ns}}$ & $-5^{\mathrm{ns}}$ & $-44^{\text {ns }}$ \\
\hline 267647 disaccharide & $-8^{\mathrm{ns}}$ & $671^{* *}$ & $2169^{* *}$ \\
\hline 285065 disaccharide & $-25^{\mathrm{ns}}$ & $74^{\star \star}$ & $59^{* *}$ \\
\hline 288331 trisaccharide & $55^{\mathrm{ns}}$ & $44^{\mathrm{ns}}$ & $100^{\mathrm{ns}}$ \\
\hline 288365 trisaccharide & $12^{\mathrm{ns}}$ & $81^{\mathrm{ns}}$ & $168^{\mathrm{ns}}$ \\
\hline 2-deoxyribose & $39^{\text {ns }}$ & $35^{\mathrm{ns}}$ & $112^{\mathrm{ns}}$ \\
\hline 2-ketoglucose dimethylacetal & $-11^{*}$ & $59^{* *}$ & $-4^{\text {ns }}$ \\
\hline 2-ketogulonic acid & $-32^{\mathrm{ns}}$ & $-84^{*}$ & $-78^{*}$ \\
\hline 304945 carbohydrate & $58^{* *}$ & $66^{* *}$ & $15^{\mathrm{ns}}$ \\
\hline 328803 carbohydrate & $14^{\mathrm{ns}}$ & $15^{\mathrm{ns}}$ & $79^{* *}$ \\
\hline 400671 carbohydrate & $71^{* \star}$ & $-2^{\text {ns }}$ & 50 \\
\hline 424905 carbohydrate & $-46^{\mathrm{ns}}$ & $-69^{*}$ & $179^{* \star}$ \\
\hline 506414 carbohydrate & $49^{* \star}$ & $184^{\text {ns }}$ & $323^{* *}$ \\
\hline 553367 disaccharide & $-52^{* *}$ & $-37^{* *}$ & $43^{* *}$ \\
\hline arabitol & $-22^{\mathrm{ns}}$ & $65^{\mathrm{ns}}$ & $147^{\mathrm{ns}}$ \\
\hline beta-glycerolphosphate & $17^{\mathrm{ns}}$ & $40^{\mathrm{ns}}$ & $146^{\mathrm{ns}}$ \\
\hline beta-hexopyranose 1,6-anhydro & $122^{\mathrm{ns}}$ & $90^{\mathrm{ns}}$ & $157^{*}$ \\
\hline
\end{tabular}




\begin{tabular}{|c|c|c|c|}
\hline digitoxose & $-25^{\mathrm{ns}}$ & $-47^{\mathrm{ns}}$ & $-35^{\mathrm{ns}}$ \\
\hline enolpyruvate & $22^{\mathrm{ns}}$ & $85^{\mathrm{ns}}$ & $246^{*}$ \\
\hline erythritol & $-2^{\text {ns }}$ & $132^{\mathrm{ns}}$ & $169^{*}$ \\
\hline erythronic acid lactone & $-18^{\mathrm{ns}}$ & $154^{* *}$ & $50^{* *}$ \\
\hline erythrose & $-30^{\text {ns }}$ & $35^{\mathrm{ns}}$ & $65^{\text {ns }}$ \\
\hline fructose 1 phosphate & $101^{\mathrm{ns}}$ & $257^{\mathrm{ns}}$ & $738^{* *}$ \\
\hline fructose-6-phosphate & $-17^{\mathrm{ns}}$ & $36^{\mathrm{ns}}$ & $75^{\mathrm{ns}}$ \\
\hline fucose & $-51^{* *}$ & $0^{\text {ns }}$ & $44^{* *}$ \\
\hline galactose & $160^{* *}$ & $975^{* *}$ & $1876^{* *}$ \\
\hline galactose-6-phosphate 1 & $-5^{\text {ns }}$ & $27^{\mathrm{ns}}$ & $107^{* *}$ \\
\hline glucoheptose & $-7^{\text {ns }}$ & $-5^{\mathrm{ns}}$ & $107^{\mathrm{ns}}$ \\
\hline glucoheptulose & $7^{\mathrm{ns}}$ & $152^{*}$ & $263^{* *}$ \\
\hline glucose & $85^{\star *}$ & $173^{* *}$ & $299^{* *}$ \\
\hline glucose-1-phosphate & $38^{*}$ & $57^{* *}$ & $116^{* *}$ \\
\hline glucose-6-phosphate 2 & $-21^{\mathrm{ns}}$ & $129^{\mathrm{ns}}$ & $413^{*}$ \\
\hline glycero-guloheptose & $-13^{\mathrm{ns}}$ & $-36^{n s}$ & $7891^{\mathrm{ns}}$ \\
\hline hexose amino-2-deoxy & $-16^{\mathrm{ns}}$ & $83^{\mathrm{ns}}$ & $192^{* *}$ \\
\hline inulotriose & $120^{\mathrm{ns}}$ & $-6^{n s}$ & $36^{\mathrm{ns}}$ \\
\hline isomaltose & $-77^{\text {ns }}$ & $95^{\mathrm{ns}}$ & $586^{* *}$ \\
\hline lactobionic acid & $110^{* *}$ & $152^{* *}$ & $247^{* *}$ \\
\hline lactose & $510^{* *}$ & $168^{\mathrm{ns}}$ & $359^{* *}$ \\
\hline leucrose & $-66^{* *}$ & $-30^{\mathrm{ns}}$ & $-56^{\star *}$ \\
\hline levanbiose & $107^{* *}$ & $90^{* *}$ & $116^{* *}$ \\
\hline levoglucosan & $-22^{\text {ns }}$ & $8^{\text {ns }}$ & $7^{\text {ns }}$ \\
\hline maltose & $132^{*}$ & $-16^{\mathrm{ns}}$ & $12^{\text {ns }}$ \\
\hline maltotriose & $9^{\text {ns }}$ & $20^{\mathrm{ns}}$ & $76^{\mathrm{ns}}$ \\
\hline mannose & $148^{* *}$ & $22^{* *}$ & $429^{* *}$ \\
\hline melezitose & $188^{\text {ns }}$ & $134^{\mathrm{ns}}$ & $422^{\text {ns }}$ \\
\hline melibiose & $-62^{* *}$ & $943^{* *}$ & $4143^{* *}$ \\
\hline methylhexose & $45^{* *}$ & $2^{\mathrm{ns}}$ & $252^{* *}$ \\
\hline N-acetyl-D-hexosamine & $43^{* *}$ & $37^{* *}$ & $73^{* *}$ \\
\hline pentitol & $29^{\mathrm{ns}}$ & $49^{\mathrm{ns}}$ & $80^{\text {ns }}$ \\
\hline propane-1,3-diol & $-8^{\text {ns }}$ & $2^{\text {ns }}$ & $15^{\text {ns }}$ \\
\hline raffinose & $162^{* *}$ & $-50^{* *}$ & $16^{\mathrm{ns}}$ \\
\hline ribitol & $96^{\mathrm{ns}}$ & $47^{\mathrm{ns}}$ & $825^{\star *}$ \\
\hline ribonic acid gamma-lactone & $-6^{\text {ns }}$ & $-14^{\mathrm{ns}}$ & $92^{\text {ns }}$ \\
\hline ribose & $548^{* *}$ & $71^{\mathrm{ns}}$ & $385^{* *}$ \\
\hline salicin & $211^{*}$ & $336^{* *}$ & $1782^{* *}$ \\
\hline \multicolumn{4}{|l|}{ Table 1 (continuation) } \\
\hline sialicin & $179^{\text {ns }}$ & $-18^{n s}$ & $98^{\mathrm{ns}}$ \\
\hline sophorose & $49^{\mathrm{ns}}$ & $127^{\text {ns }}$ & $297^{* *}$ \\
\hline
\end{tabular}




\begin{tabular}{|l|l|l|l|}
\hline sucrose-6-phosphate & $-42^{\text {ns }}$ & $79^{\text {ns }}$ & $185^{\mathrm{ns}}$ \\
\hline tagatose & $-24^{\mathrm{ns}}$ & $22^{\mathrm{ns}}$ & $175^{\mathrm{ns}}$ \\
\hline threitol & $-15^{\mathrm{ns}}$ & $111^{\mathrm{ns}}$ & $418^{\mathrm{ns}}$ \\
\hline trehalose & $-33^{\mathrm{ns}}$ & $-17^{\mathrm{ns}}$ & $133^{* *}$ \\
\hline furanose & $54^{\mathrm{ns}}$ & $21^{\mathrm{ns}}$ & $164^{\mathrm{ns}}$ \\
\hline xylitol & $91^{* *}$ & $155^{\text {**}}$ & $146^{* *}$ \\
\hline xylonolactone & $41^{\mathrm{ns}}$ & $32^{\mathrm{ns}}$ & $71^{\mathrm{ns}}$ \\
\hline xylulose & $458^{* *}$ & $228^{\mathrm{ns}}$ & $1264^{\star *}$ \\
\hline
\end{tabular}

ns: no significant; $* p<0.05 ; * * p<0.01$ 


\section{Table 2 (on next page)}

Amino acids identified on sugarcane methanolic leaves extracts by GC-MS TOF

The treatments were inoculation with $G$. diazotrophicus and $H$. seropedicae (PGPB), bacteria and humic acid (PGPB+HA) or only humic acid (HA) isolated from vermicompost. The data were expressed in respect to control treatment (\%). 
Table 2. Amino acids identified on sugarcane methanolic leaves extracts by GC-MS TOF. The treatments were inoculation with $G$. diazotrophicus and $H$. seropedicae (PGPB), bacteria and humic acid (PGPB+HA) or only humic acid (HA) isolated from vermicompost. The data were expressed in respect to control treatment $(\%)$.

\begin{tabular}{|c|c|c|c|}
\hline metabolite & HA & PGPB & PGPB+HA \\
\hline 3-aminoisobutyric acid & $12^{\text {ns }}$ & $1^{\mathrm{ns}}$ & $-20^{\text {ns }}$ \\
\hline 4-hydroxyproline & $1^{\mathrm{ns}}$ & $94^{* *}$ & $369^{* *}$ \\
\hline 5-aminovaleric acid & $212^{* *}$ & $24^{\text {ns }}$ & $64^{\mathrm{ns}}$ \\
\hline 5-hydroxynorvaline & $-26^{\mathrm{ns}}$ & $154^{\star *}$ & $52^{\mathrm{ns}}$ \\
\hline asparagine & $-85^{\star *}$ & $177^{\text {ns }}$ & $937^{\mathrm{ns}}$ \\
\hline aspartic acid & $16^{\mathrm{ns}}$ & $122^{* *}$ & $629^{* *}$ \\
\hline$\beta$-alanine & $15^{\mathrm{ns}}$ & $-21^{\mathrm{ns}}$ & $0^{\text {ns }}$ \\
\hline citrulline & $-18^{\mathrm{ns}}$ & $359^{*}$ & $276^{\mathrm{ns}}$ \\
\hline cyano-L-alanine & $-3^{\text {ns }}$ & $155^{\text {ns }}$ & $186^{\mathrm{ns}}$ \\
\hline glutamic acid & $14^{\text {ns }}$ & $254^{* *}$ & $250^{* *}$ \\
\hline glutamine & $-72^{\text {ns }}$ & $1038^{* *}$ & $595^{\star *}$ \\
\hline glycine & $-14^{* *}$ & $0^{\text {ns }}$ & $107^{* *}$ \\
\hline homoserine & $-38^{n s}$ & $216^{*}$ & $640^{* *}$ \\
\hline isoleucine & $45^{* *}$ & $88^{* *}$ & $135^{\star *}$ \\
\hline lysine & $202^{\text {ns }}$ & $220^{\mathrm{ns}}$ & $830^{\mathrm{ns}}$ \\
\hline methionine & $-42^{n s}$ & $161^{\text {ns }}$ & $199^{\text {ns }}$ \\
\hline $\mathrm{N}$-acetylornithine & $17^{\mathrm{ns}}$ & $95^{\mathrm{ns}}$ & $237^{\text {ns }}$ \\
\hline N-hexanoylglycine & $184^{\mathrm{ns}}$ & $404^{\text {ns }}$ & $646^{\mathrm{ns}}$ \\
\hline $\mathrm{N}$-methylalanine & $-40^{n s}$ & $101^{* *}$ & $99^{* *}$ \\
\hline O-acetylserine & $16^{\mathrm{ns}}$ & $10^{\mathrm{ns}}$ & $94^{\mathrm{ns}}$ \\
\hline oxoproline & $26^{* *}$ & $192^{* *}$ & $320^{* *}$ \\
\hline phenylalanine & $126^{\text {ns }}$ & $1004^{* *}$ & $819^{* *}$ \\
\hline proline & $278^{* *}$ & $1031^{* *}$ & $1155^{* *}$ \\
\hline serine & $-3^{\text {ns }}$ & $253^{* *}$ & $81^{* *}$ \\
\hline threonine & $34^{\mathrm{ns}}$ & $414^{* *}$ & $101^{* *}$ \\
\hline thymine & $-15^{\mathrm{ns}}$ & $216^{* *}$ & $367^{* *}$ \\
\hline
\end{tabular}

ns: no significant; $* p<0.05 ; * * p<0.01$ 


\section{Table 3(on next page)}

Organic acids identified on sugarcane methanolic leaves extracts by GC-MS TOF.

The treatments were inoculation with $G$. diazotrophicus and $H$. seropedicae (PGPB), bacteria and humic acid (PGPB+HA) or only humic acid (HA) isolated from vermicompost. The data were expressed in respect to control treatment (\%). 
Table 3. Organic acids identified on sugarcane methanolic leaves extracts by GC-MS TOF. The treatments were inoculation with $G$. diazotrophicus and $H$. seropedicae (PGPB), bacteria and humic acid (PGPB+HA) or only humic acid (HA) isolated from vermicompost. The data were expressed in respect to control treatment (\%).

\begin{tabular}{|c|c|c|c|}
\hline metabolite & HA & PGPB & PGPB+HA \\
\hline 2,3-dihydroxybutanoic acid & $30^{\mathrm{ns}}$ & $31^{\mathrm{ns}}$ & $66^{\mathrm{ns}}$ \\
\hline 2,5-furandicarboxylic acid & $8^{\mathrm{ns}}$ & $19^{\mathrm{ns}}$ & $85^{\mathrm{ns}}$ \\
\hline 2-deoxyribonic acid & $-11^{\text {ns }}$ & $-11^{\text {ns }}$ & $28^{\mathrm{ns}}$ \\
\hline 2-deoxytetronic acid & $95^{\mathrm{ns}}$ & $95^{\mathrm{ns}}$ & $100^{\mathrm{ns}}$ \\
\hline 2-hydroxyadipic acid & $68^{\mathrm{ns}}$ & $7^{\text {ns }}$ & $185^{\mathrm{ns}}$ \\
\hline 2-hydroxyglutaric acid & $262^{\text {ns }}$ & $77^{\mathrm{ns}}$ & $57^{\mathrm{ns}}$ \\
\hline 2-ketoadipic acid & $-37^{\text {ns }}$ & $8^{\text {ns }}$ & $-36^{\text {ns }}$ \\
\hline 2-oxogluconic acid & $65^{\mathrm{ns}}$ & $264^{\mathrm{ns}}$ & $730^{* *}$ \\
\hline 3-hydroxy-3-methylglutaric acid & $-23^{\text {ns }}$ & $-4^{\text {ns }}$ & $5^{\text {ns }}$ \\
\hline 3-hydroxypropionic acid & $27^{\mathrm{ns}}$ & $31^{\mathrm{ns}}$ & $87^{* *}$ \\
\hline 4-hydroxybutyric acid & $27^{\mathrm{ns}}$ & $25^{\mathrm{ns}}$ & $50^{\mathrm{ns}}$ \\
\hline 5-hydroxymethyl-2-furoic acid & $-12^{\text {ns }}$ & $-3^{\text {ns }}$ & $33^{\mathrm{ns}}$ \\
\hline adipic acid & $8^{\text {ns }}$ & $8^{\text {ns }}$ & $26^{\mathrm{ns}}$ \\
\hline alpha ketoglutaric acid & $7^{*}$ & $22^{*}$ & $83^{* *}$ \\
\hline aminomalonic acid & $36^{\mathrm{ns}}$ & $116^{\text {ns }}$ & $83^{\mathrm{ns}}$ \\
\hline ascorbic acid & $114^{\text {ns }}$ & $155^{\mathrm{ns}}$ & $368^{* *}$ \\
\hline citramalic acid & $-8^{\text {ns }}$ & $-27^{\text {ns }}$ & $-49^{\text {ns }}$ \\
\hline citric acid & $98^{* *}$ & $416^{* *}$ & $748^{* *}$ \\
\hline dihydroxymalonic acid & $-72^{\text {ns }}$ & $0^{\text {ns }}$ & $298^{* *}$ \\
\hline fumaric acid & $2^{\text {ns }}$ & $-47^{\text {ns }}$ & $126^{* *}$ \\
\hline galactonic acid & $-39^{\text {ns }}$ & $34^{\mathrm{ns}}$ & $37^{\mathrm{ns}}$ \\
\hline gluconic acid & $4^{\mathrm{ns}}$ & $34^{\mathrm{ns}}$ & $77^{\mathrm{ns}}$ \\
\hline gluconic acid lactone & $105^{\mathrm{ns}}$ & $330^{* *}$ & $412^{* *}$ \\
\hline glutaric acid & $12^{\mathrm{ns}}$ & $179^{\mathrm{ns}}$ & $184^{\mathrm{ns}}$ \\
\hline glycolic acid & $-16^{\text {ns }}$ & $1^{\mathrm{ns}}$ & $19^{\text {ns }}$ \\
\hline hexuronic acid & $-9^{\text {ns }}$ & $85^{\mathrm{ns}}$ & $305^{*}$ \\
\hline idonic acid & $150^{*}$ & $150^{*}$ & $268^{* *}$ \\
\hline isocitric lactone & $145^{\star \star}$ & $10^{\mathrm{ns}}$ & $140^{* *}$ \\
\hline isothreonic acid & $30^{\mathrm{ns}}$ & $103^{* *}$ & $211^{* *}$ \\
\hline itaconic acid & $-50^{\star *}$ & $31^{* *}$ & $28^{* *}$ \\
\hline lactic acid & $76^{* *}$ & $22^{* *}$ & $43^{* *}$ \\
\hline maleic acid & $305^{\star *}$ & $263^{* *}$ & $122^{* *}$ \\
\hline mannonic acid & $27^{\mathrm{ns}}$ & $160^{\mathrm{ns}}$ & $173^{\mathrm{ns}}$ \\
\hline methylmaleic acid & $-11^{\mathrm{ns}}$ & $44^{\mathrm{ns}}$ & $60^{\mathrm{ns}}$ \\
\hline mucic acid & $-47^{* *}$ & $127^{* *}$ & $408^{* *}$ \\
\hline \multicolumn{4}{|l|}{ Table 3 - continuation } \\
\hline metabolite & HA & PGPB & PGPB+HA \\
\hline
\end{tabular}




\begin{tabular}{|l|l|l|l|}
\hline oxalic acid & $745^{\star *}$ & $18^{* *}$ & $259^{* *}$ \\
\hline pantothenic acid & $11^{\mathrm{ns}}$ & $81^{* *}$ & $307^{* *}$ \\
\hline propane-1,2,3-tricarboxylate /carballylic acid & $80^{\mathrm{ns}}$ & $55^{\mathrm{ns}}$ & $174^{\mathrm{ns}}$ \\
\hline pyruvic acid & $-61^{* *}$ & $0^{\mathrm{ns}}$ & $29^{* *}$ \\
\hline ribonic acid & $33^{*}$ & $46^{\star *}$ & $155^{\star *}$ \\
\hline saccharic acid & $133^{* *}$ & $-13^{\mathrm{ns}}$ & $235^{* *}$ \\
\hline salicylic acid & $-26^{\mathrm{ns}}$ & $44^{\mathrm{ns}}$ & $72^{*}$ \\
\hline succinate semialdehyde/4-oxobutanoic acid & $-4^{\mathrm{ns}}$ & $31^{\mathrm{ns}}$ & $48^{\mathrm{ns}}$ \\
\hline succinic acid & $-23^{*}$ & $-27^{* *}$ & $-15^{\mathrm{ns}}$ \\
\hline
\end{tabular}

ns: no significant; $* p<0.05 ; * * p<0.01$ 


\section{Table 4(on next page)}

Nitrogenous (other than amino acids) identified on sugarcane methanolic leaves extracts by GC-MS TOF.

The treatments were inoculation with $G$. diazotrophicus and $H$. seropedicae (PGPB), bacteria and humic acid (PGPB $+\mathrm{HA})$ or only humic acid $(\mathrm{HA})$ isolated from vermicompost. The data were expressed in respect to control treatment (\%). 
Table 4. Nitrogenous (other than amino acids) identified on sugarcane methanolic leaves extracts by GC-MS TOF. The treatments were inoculation with $G$. diazotrophicus and $H$. seropedicae (PGPB), bacteria and humic acid (PGPB+HA) or only humic acid (HA) isolated from vermicompost. The data were expressed in respect to control treatment (\%).

\begin{tabular}{|c|c|c|c|}
\hline Nitrogenous (other than amino acids) & HA & PGPB & PGPB+HA \\
\hline 1,3-diaminopropane & $131^{*}$ & $47^{\mathrm{ns}}$ & $196^{* *}$ \\
\hline 2-deoxyadenosine & $736^{*}$ & $-14^{\mathrm{ns}}$ & $65^{* *}$ \\
\hline 2'-deoxyguanosine & $108^{\mathrm{ns}}$ & $1179^{* *}$ & $997^{* *}$ \\
\hline 3,6-dihydro-3,6-dimethyl-2,5-bishydroxypyrazine & $4^{\mathrm{ns}}$ & $-13^{n s}$ & $-1^{\text {ns }}$ \\
\hline 3-hydroxypyridine & $20^{\mathrm{ns}}$ & $175^{\text {ns }}$ & $356^{* *}$ \\
\hline 4-hydroxyquinoline-2-carboxylic acid & $650^{* *}$ & $-40^{n s}$ & $255^{\star *}$ \\
\hline 5'-deoxy-5'-methylthioadenosine & $4^{\mathrm{ns}}$ & $56^{\mathrm{ns}}$ & $157^{* *}$ \\
\hline 5-methylcytosine & $31^{\mathrm{ns}}$ & $349^{\text {ns }}$ & $503^{*}$ \\
\hline 6-hydroxynicotinic acid & $35^{\text {ns }}$ & $26^{\text {ns }}$ & $21^{\mathrm{ns}}$ \\
\hline adenine & $377^{* *}$ & $3817^{* *}$ & $4971^{* *}$ \\
\hline adenosine & $-77^{* *}$ & $226^{* *}$ & $116^{* *}$ \\
\hline biuret & $-4^{\text {ns }}$ & $72^{\text {ns }}$ & $94^{\text {ns }}$ \\
\hline butyrolactam & $-4^{\text {ns }}$ & $800^{* *}$ & $708^{* *}$ \\
\hline carnitine & $10^{\mathrm{ns}}$ & $-10^{\mathrm{ns}}$ & $384^{* *}$ \\
\hline cytidine & $15^{\mathrm{ns}}$ & $19^{\text {ns }}$ & $151^{\mathrm{ns}}$ \\
\hline cytosin & $5^{\mathrm{ns}}$ & $368^{*}$ & $517^{* *}$ \\
\hline ethanolamine & $192^{* *}$ & $86^{* *}$ & $94^{* *}$ \\
\hline guanine & $-50^{\mathrm{ns}}$ & $777^{\text {ns }}$ & $2119^{*}$ \\
\hline guanosine & $14^{\mathrm{ns}}$ & $1^{\mathrm{ns}}$ & $19^{\text {ns }}$ \\
\hline inosine & $52^{\mathrm{ns}}$ & $-19^{n s}$ & $12^{\mathrm{ns}}$ \\
\hline isonicotinic acid & $34^{\mathrm{ns}}$ & $260^{* *}$ & $544^{* *}$ \\
\hline maleimide & $-16^{\mathrm{ns}}$ & $60^{\text {ns }}$ & $527^{* *}$ \\
\hline nicotinamide & $34^{\mathrm{ns}}$ & $17^{\mathrm{ns}}$ & $57^{\mathrm{ns}}$ \\
\hline orotic acid & $19^{\text {ns }}$ & $47^{\text {ns }}$ & $214^{* *}$ \\
\hline putrescine & $75^{* *}$ & $123^{* *}$ & $405^{\star *}$ \\
\hline pyrrole-2-carboxylic acid & $25^{\mathrm{ns}}$ & $30^{\mathrm{ns}}$ & $108^{\mathrm{ns}}$ \\
\hline spermidine 2 & $4^{\mathrm{ns}}$ & $106^{\mathrm{ns}}$ & $749^{*}$ \\
\hline taurine & 16 & -3 & 21 \\
\hline thymidine & $-56^{* *}$ & $125^{\star *}$ & $247^{* *}$ \\
\hline uracil & $-30^{\mathrm{ns}}$ & $213^{* *}$ & $81^{* *}$ \\
\hline xanthine & $-9^{\text {ns }}$ & $-25^{\mathrm{ns}}$ & $114^{\text {ns }}$ \\
\hline xanthosine & $11^{\mathrm{ns}}$ & $-21^{\mathrm{ns}}$ & $-5^{\text {ns }}$ \\
\hline xanthurenic acid & $7^{\mathrm{ns}}$ & $6^{\mathrm{ns}}$ & $63^{\mathrm{ns}}$ \\
\hline
\end{tabular}

ns: no significant; ${ }^{*} p<0.05 ; * * p<0.01$ 


\section{Table 5 (on next page)}

Lipids identified on sugarcane methanolic leaves extracts by GC-MS TOF.

The treatments were inoculation with $G$. diazotrophicus and $H$. seropedicae (PGPB), bacteria and humic acid (PGPB+HA) or only humic acid (HA) isolated from vermicompost. The data were expressed in respect to control treatment (\%). 
Table 5. Lipids identified on sugarcane methanolic leaves extracts by GC-MS TOF. The treatments were inoculation with $G$. diazotrophicus and $H$. seropedicae (PGPB), bacteria and humic acid (PGPB+HA) or only humic acid (HA) isolated from vermicompost. The data were expressed in respect to control treatment (\%).

\begin{tabular}{|c|c|c|c|}
\hline metabolite & HA & PGPB & PGPB+HA \\
\hline 1-hexadecanol & $52^{\text {ns }}$ & $17^{\text {ns }}$ & $136^{\mathrm{ns}}$ \\
\hline 1-monopalmiteolin & $9^{\text {ns }}$ & $-5^{\mathrm{ns}}$ & $123^{\mathrm{ns}}$ \\
\hline 1-monopalmitin & $2^{\text {ns }}$ & $30^{\mathrm{ns}}$ & $120^{\mathrm{ns}}$ \\
\hline 223494 fatty acid methyl ester & $21^{\text {ns }}$ & $-16^{\mathrm{ns}}$ & $54^{\text {ns }}$ \\
\hline 2-hydroxyvaleric acid & $-28^{\text {ns }}$ & $7^{\mathrm{ns}}$ & $10^{\text {ns }}$ \\
\hline 2-monoolein & $-59^{* *}$ & $25^{*}$ & $43^{* *}$ \\
\hline 2-monopalmitin & $113^{\text {ns }}$ & $-35^{\mathrm{ns}}$ & $357^{* *}$ \\
\hline 2-monostearin & $-4^{\mathrm{ns}}$ & $3^{\text {ns }}$ & $168^{*}$ \\
\hline 2-palmitoleic acid & $-22^{\text {ns }}$ & $-20^{\mathrm{ns}}$ & $133^{\mathrm{ns}}$ \\
\hline 6-hydroxycaproate dimer & $-82^{* *}$ & $103^{* *}$ & $134^{* *}$ \\
\hline 6-hydroxycaproic acid & $49^{\text {ns }}$ & $70^{\text {ns }}$ & $99^{\text {ns }}$ \\
\hline arachidic acid & $9^{\text {ns }}$ & $-28^{\mathrm{ns}}$ & $4^{\mathrm{ns}}$ \\
\hline azelaic acid & $-36^{\text {ns }}$ & $14^{\text {ns }}$ & $105^{\text {ns }}$ \\
\hline behenic acid & $193^{* *}$ & $-36^{\mathrm{ns}}$ & $439^{* *}$ \\
\hline beta-sitosterol & $460^{* *}$ & $191^{* *}$ & $765^{\star *}$ \\
\hline caffeic acid & $28^{\text {ns }}$ & $37^{\text {ns }}$ & $65^{\text {ns }}$ \\
\hline capric acid & $60^{* *}$ & $12^{\mathrm{ns}}$ & $47^{*}$ \\
\hline cerotic acid & $8^{\mathrm{ns}}$ & $46^{\mathrm{ns}}$ & $464^{* *}$ \\
\hline cholesterol & $222^{*}$ & $-7^{\mathrm{ns}}$ & $342^{* *}$ \\
\hline cis-4-decene-1,10-dioic acid & $142^{*}$ & $106^{\mathrm{ns}}$ & $429^{* *}$ \\
\hline dihydrosphingosine & $47^{\text {ns }}$ & $210^{*}$ & $692^{* *}$ \\
\hline dodecane & $54^{\text {ns }}$ & $12^{\text {ns }}$ & $11^{\text {ns }}$ \\
\hline dodecanol & $8^{\mathrm{ns}}$ & $22^{\text {ns }}$ & $7^{\mathrm{ns}}$ \\
\hline eicosenoic acid & $167^{* *}$ & $-37^{\mathrm{ns}}$ & $417^{* *}$ \\
\hline gamma-tocopherol & $14^{\text {ns }}$ & $-1^{\text {ns }}$ & $123^{*}$ \\
\hline isopalmitic acid & $18^{\text {ns }}$ & $43^{\text {ns }}$ & $55^{\text {ns }}$ \\
\hline lauric acid & $179^{* *}$ & $165^{* *}$ & $202^{* *}$ \\
\hline lignoceric acid & $-13^{\text {ns }}$ & $-61^{* *}$ & $61^{* *}$ \\
\hline linoleic acid & $2^{\text {ns }}$ & $76^{* *}$ & $286^{* *}$ \\
\hline linoleic acid methyl ester & $8^{\mathrm{ns}}$ & $42^{\text {ns }}$ & $99^{* *}$ \\
\hline linolenic acid & $-6^{\mathrm{ns}}$ & $51^{\mathrm{ns}}$ & $597^{* *}$ \\
\hline methylhexadecanoic acid & $34^{*}$ & $364^{* *}$ & $579 * *$ \\
\hline monoolein & $43^{* *}$ & $-7^{*}$ & $-41^{* *}$ \\
\hline montanic acid & $-3^{n s}$ & $-19^{\text {ns }}$ & $15^{\mathrm{ns}}$ \\
\hline myristic acid & $100^{\mathrm{ns}}$ & $20^{\text {ns }}$ & $175^{*}$ \\
\hline octadecanol & $-11^{\text {ns }}$ & $0^{\mathrm{ns}}$ & $-8^{\mathrm{ns}}$ \\
\hline Table 5 (continuation) & & & \\
\hline
\end{tabular}




\begin{tabular}{|l|l|l|l|}
\hline \multicolumn{1}{|c|}{ metabolite } & HA & PGPB & PGPB+HA \\
\hline oleic acid & $-8^{\text {ns }}$ & $22^{\text {ns }}$ & $92^{\text {ns }}$ \\
\hline palmitic acid & $-11^{\text {** }}$ & $9^{* *}$ & $32^{\text {** }}$ \\
\hline palmitoleic acid & $41^{\text {ns }}$ & $71^{\text {ns }}$ & $297^{* *}$ \\
\hline pelargonic acid & $38^{* *}$ & $117^{\text {** }}$ & $69^{* *}$ \\
\hline pentadecanoic acid monoacylglycerol ester & $-5^{\text {ns }}$ & $-2^{\text {ns }}$ & $94^{\text {ns }}$ \\
\hline phytol & $-84^{* *}$ & $17^{\text {ns }}$ & $454^{\text {** }}$ \\
\hline pimelic acid & $-30^{\text {ns }}$ & $-37^{\text {ns }}$ & $104^{* *}$ \\
\hline squalene & $-43^{\text {ns }}$ & $5^{\text {ns }}$ & $124^{* *}$ \\
\hline stigmasterol & $-29^{\text {ns }}$ & $-2^{\text {ns }}$ & $76^{\text {ns }}$ \\
\hline suberyl glycine & $-20^{\text {ns }}$ & $-19^{\text {ns }}$ & $39^{\text {ns }}$ \\
\hline a-tocopherol & $8^{\text {ns }}$ & $2^{\text {ns }}$ & $49^{*}$ \\
\hline
\end{tabular}

ns: no significant; ${ }^{*} p<0.05 ; * * p<0.01$ 


\section{Table 6(on next page)}

Aromatics compounds identified on sugarcane methanolic leaves extracts

The treatments were inoculation with $G$. diazotrophicus and $H$. seropedicae (PGPB), bacteria and humic acid (PGPB+HA) or only humic acid (HA) isolated from vermicompost. The data were expressed in respect to control treatment (\%). 
Table 6. Aromatics compounds identified on sugarcane methanolic leaves extracts. The treatments were inoculation with $G$. diazotrophicus and $H$. seropedicae (PGPB), bacteria and humic acid (PGPB+HA) or only humic acid (HA) isolated from vermicompost. The data were expressed in respect to control treatment (\%).

\begin{tabular}{|c|c|c|c|}
\hline metabolite & HA & PGPB & PGPB+HA \\
\hline vanillic acid & $18^{\mathrm{ns}}$ & $24^{\mathrm{ns}}$ & $60^{*}$ \\
\hline syringic acid & $46^{\text {ns }}$ & $-11^{\mathrm{ns}}$ & $83^{*}$ \\
\hline shikimic acid & $311^{* *}$ & $22^{* *}$ & $385^{\star *}$ \\
\hline pyrogallol & $-9^{\text {ns }}$ & $39^{\mathrm{ns}}$ & $64^{\mathrm{ns}}$ \\
\hline pyrazine 2,5-dihydroxy & $60^{\text {ns }}$ & $85^{\mathrm{ns}}$ & $189^{\text {ns }}$ \\
\hline pipecolic acid & $-77^{* *}$ & $197^{\star *}$ & $450^{* *}$ \\
\hline p-hydroquinone & $29^{\text {ns }}$ & $77^{\mathrm{ns}}$ & $122^{\text {ns }}$ \\
\hline phthalic acid & $-29^{*}$ & $72^{* *}$ & $117^{* *}$ \\
\hline phenylethylamine & $-63^{\mathrm{ns}}$ & $-13^{\text {ns }}$ & $4^{\mathrm{ns}}$ \\
\hline phenylacetic acid & $2^{\mathrm{ns}}$ & $-9^{\text {ns }}$ & $29^{\mathrm{ns}}$ \\
\hline parabanic acid & $13^{\text {ns }}$ & $62^{\text {ns }}$ & $137^{* *}$ \\
\hline oxamic acid & $69^{\text {ns }}$ & $50^{\mathrm{ns}}$ & $92^{\mathrm{ns}}$ \\
\hline gentisic acid & $45^{\text {ns }}$ & $-1^{\text {ns }}$ & $35^{\mathrm{ns}}$ \\
\hline ferulic acid & $-28^{\mathrm{ns}}$ & $59^{\mathrm{ns}}$ & $175^{\text {ns }}$ \\
\hline dihydroabietic acid & $-29^{\text {ns }}$ & $17^{\mathrm{ns}}$ & $78^{\mathrm{ns}}$ \\
\hline coniferin & $-77^{*}$ & $-33^{\mathrm{ns}}$ & $201^{* *}$ \\
\hline cis-caffeic acid & $294^{* *}$ & $138^{*}$ & $494^{* *}$ \\
\hline chlorogenic acid & $-20^{\text {ns }}$ & $133^{*}$ & $-30^{\text {ns }}$ \\
\hline arbutin & $204^{* *}$ & $21^{\mathrm{ns}}$ & $127^{* *}$ \\
\hline 4-hydroxyphenylacetic acid & $6^{\mathrm{ns}}$ & $12^{\text {ns }}$ & $12^{\text {ns }}$ \\
\hline 4-hydroxymandelic acid & $-45^{\text {ns }}$ & $17^{\mathrm{ns}}$ & $-24^{\text {ns }}$ \\
\hline 4-hydroxycinnamic acid & $100^{* *}$ & $-6^{\mathrm{ns}}$ & $-19^{* *}$ \\
\hline 4-hydroxybenzoate & $19^{\text {ns }}$ & $1^{\mathrm{ns}}$ & $98^{* *}$ \\
\hline 4-hydroxybenzaldehyde & $63^{\text {ns }}$ & $-48^{\mathrm{ns}}$ & $87^{* *}$ \\
\hline 3-hydroxybenzoic acid & $-5^{\mathrm{ns}}$ & $27^{\mathrm{ns}}$ & $-20^{\text {ns }}$ \\
\hline 3,4-dihydroxybenzoic acid & $46^{* *}$ & $58^{* *}$ & $29^{* *}$ \\
\hline 2-phenylpropanol & $47^{\mathrm{ns}}$ & $10^{\mathrm{ns}}$ & $15^{\mathrm{ns}}$ \\
\hline 2-(4-hydroxyphenyl)ethanol & $-11^{\mathrm{ns}}$ & $-12^{\mathrm{ns}}$ & $108^{* *}$ \\
\hline 2,3-dihydroxypyridine & $1^{\mathrm{ns}}$ & $-9^{\text {ns }}$ & $-3^{\text {ns }}$ \\
\hline 2,3-dihydroxybenzoic acid & $12^{* *}$ & $52^{* *}$ & $80 * *$ \\
\hline 1,2,4-benzenetriol & $14^{\text {ns }}$ & $-9^{\text {ns }}$ & $39^{\text {ns }}$ \\
\hline
\end{tabular}

ns: no significant; $* p<0.05 ; * * p<0.01$ 


\section{Figure 1}

Schematic representation of the effect of the treatments on the levels of amino acids in respect to control

Schematic representation of the effect of the treatments on the levels of amino acids in respect to control. Rectangles containing aminoacids pools that derivates from pathways conversions of 3-phosphoglycerate (PGA), P-enolpyruvate, pyruvate., oxaloacetate and $\alpha$ ketoglutarate. Aminoacids with significant higher values related to control had shown color circles. The color circles represent the treatments (HA: black; PGPB: blue, HA+PGPB: red) and the magnitude of influence of each treatment in respect to control is represented by the circle size.
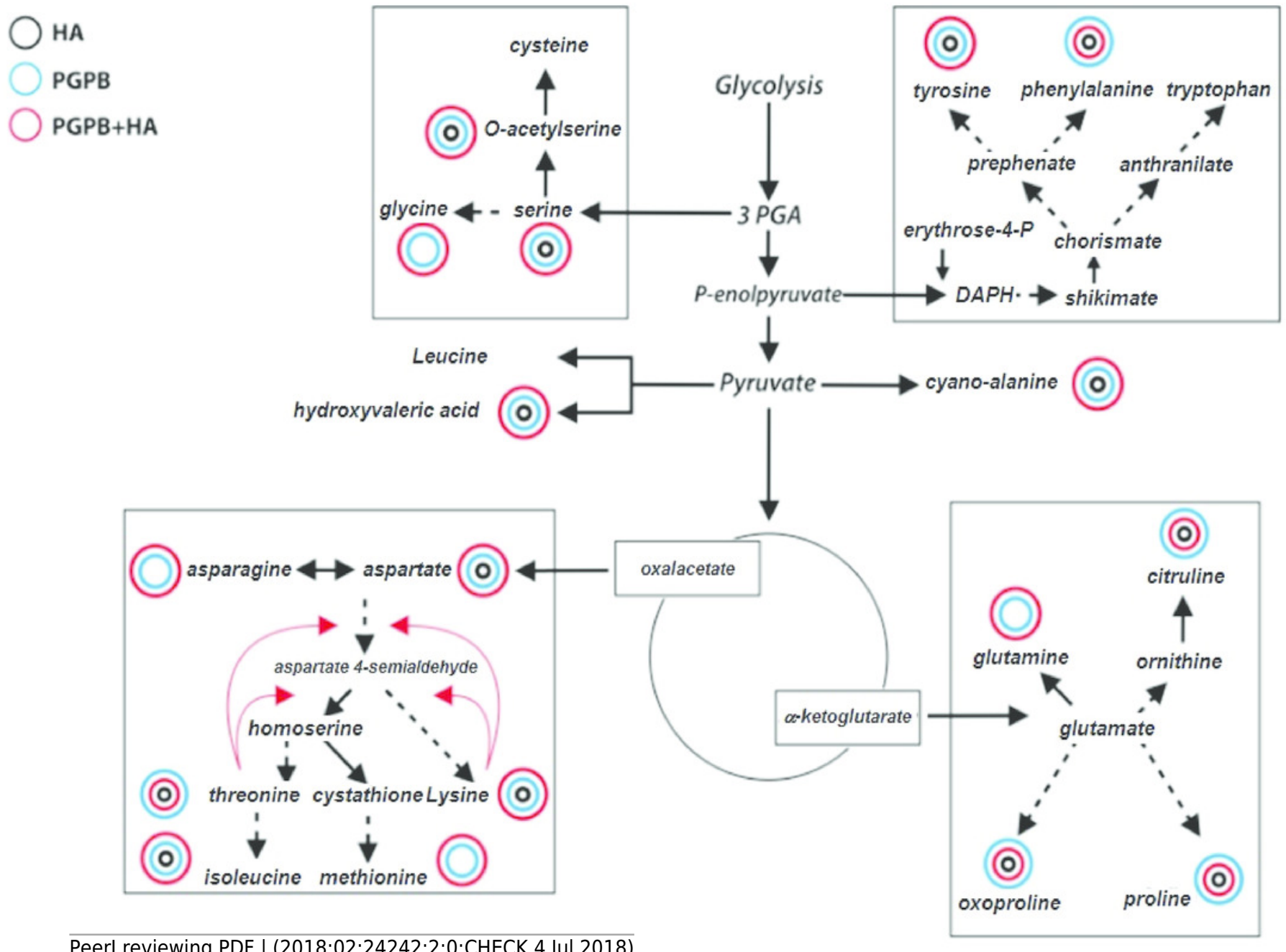
Figure 2

PCA scores for CG-MS metabolic profile data

PCA scores for CG-MS data indicating good separation of treatments in different groups according to bacteria inoculation (PGPB), humic acid (HA) application or its combined use (HA + PGPB) for metabolomic profiles, as well good agreement among biological replicates.

The loadings and their coefficient weight that indicates the position of the variables along the PCs and consequently their importance for that PC are showed in supplementary file.

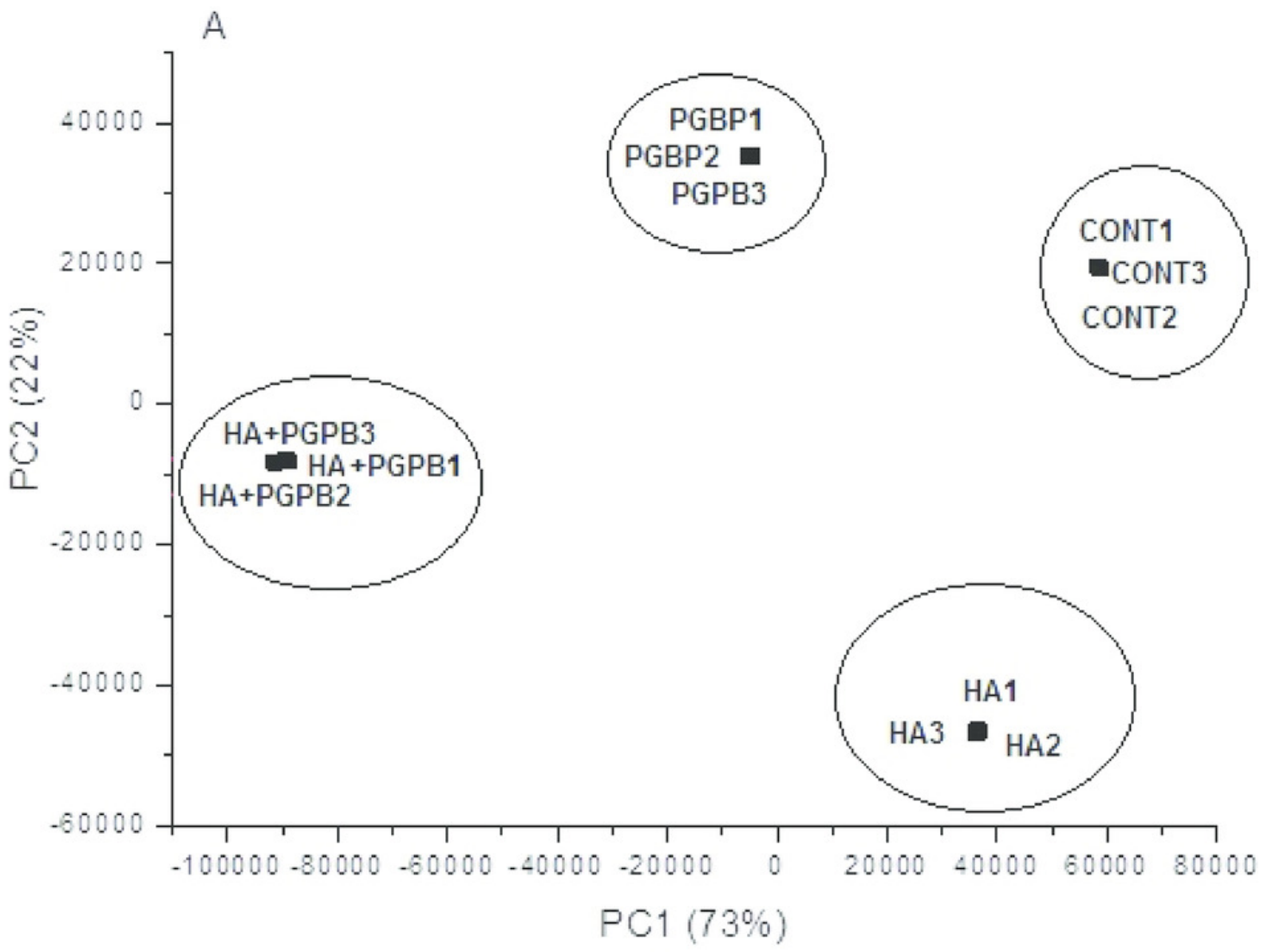




\section{Figure 3}

General view of the most important metabolites identified on main sugarcane biochemical pathways.

Representation of the most important metabolites identified on main sugarcane biochemical pathways. The color squares represent the treatments (HA: black; PGPB: blue, HA+PGPB: red) and the increase of concentration level (\% in respect to control) was ranking according to the color-coded scale bar that range from 100 to $500 \times$ times concentration related to control plants.

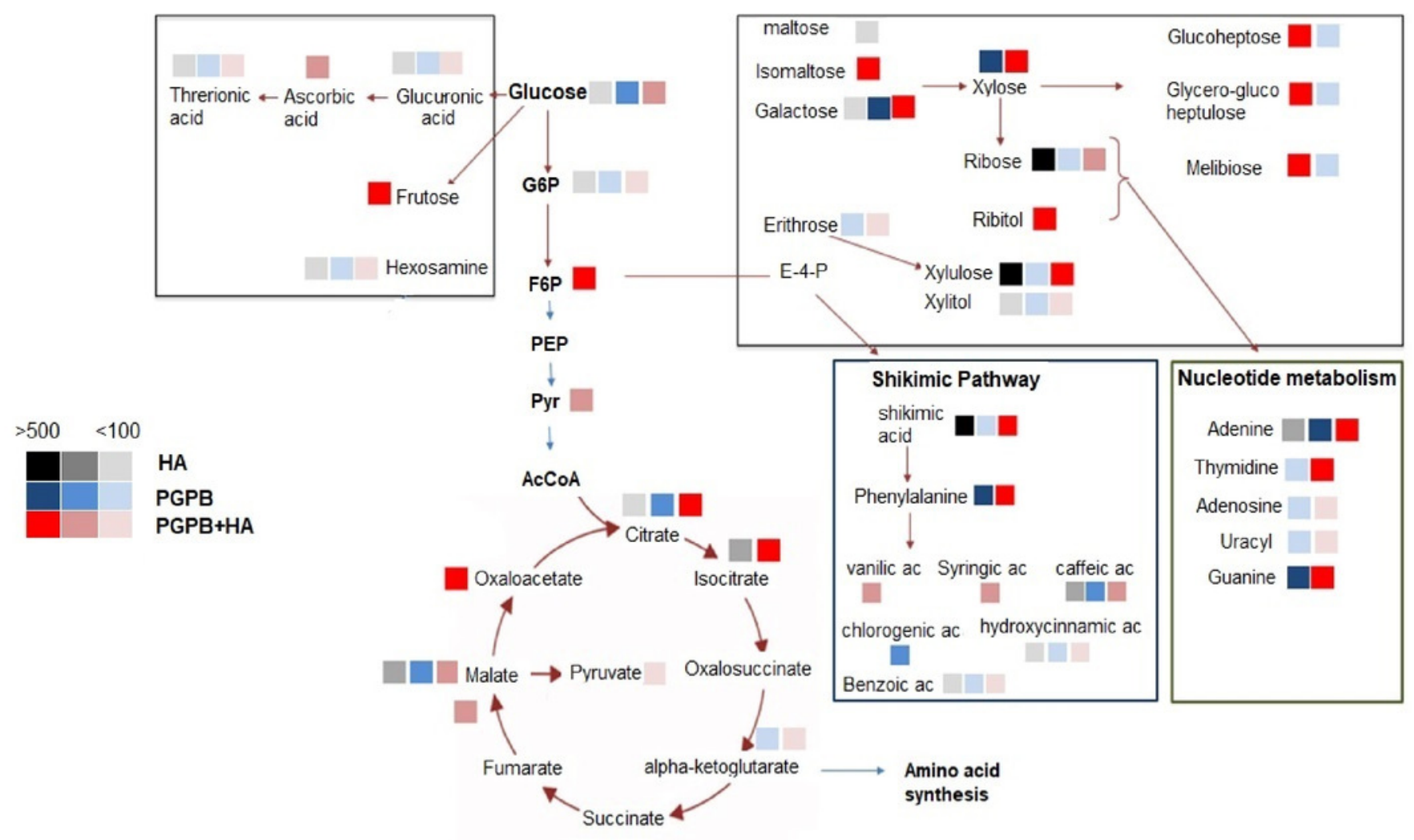

